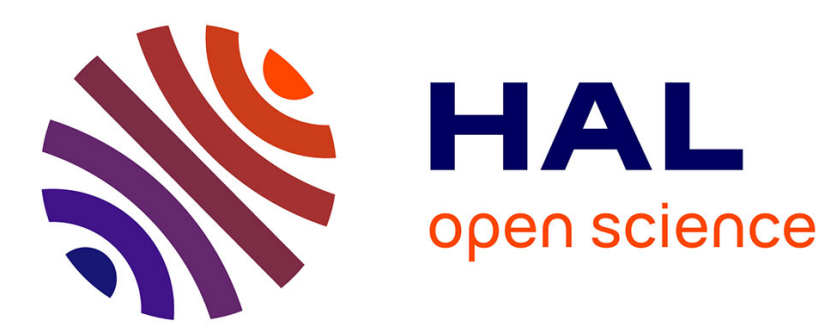

\title{
Lung function and overweight in school aged children after early childhood wheezing
}

Virpi H Sidoroff, Mari K Hyvärinen, Eija Piippo-Savolainen, Matti Korppi

\section{To cite this version:}

Virpi H Sidoroff, Mari K Hyvärinen, Eija Piippo-Savolainen, Matti Korppi. Lung function and overweight in school aged children after early childhood wheezing. Pediatric Pulmonology, 2010, 10.1002/ppul.21386 . hal-00604878

\section{HAL Id: hal-00604878 \\ https://hal.science/hal-00604878}

Submitted on 30 Jun 2011

HAL is a multi-disciplinary open access archive for the deposit and dissemination of scientific research documents, whether they are published or not. The documents may come from teaching and research institutions in France or abroad, or from public or private research centers.
L'archive ouverte pluridisciplinaire HAL, est destinée au dépôt et à la diffusion de documents scientifiques de niveau recherche, publiés ou non, émanant des établissements d'enseignement et de recherche français ou étrangers, des laboratoires publics ou privés. 


\section{Lung function and overweight in school aged children after early childhood wheezing}

\begin{tabular}{|c|c|}
\hline Journal: & Pediatric Pulmonology \\
\hline Manuscript ID: & PPUL-10-0168.R1 \\
\hline Wiley - Manuscript type: & Original Article \\
\hline $\begin{array}{l}\text { Date Submitted by the } \\
\text { Author: }\end{array}$ & 01-Nov-2010 \\
\hline Complete List of Authors: & $\begin{array}{l}\text { Sidoroff, Virpi; University of Eastern Finland; Kuopio University } \\
\text { Hospital, Department of Pediatrics } \\
\text { Hyvärinen, Mari; Kuopio University Hospital, Department of } \\
\text { Pediatrics } \\
\text { Piippo-Savolainen, Eija; Kuopio University Hospital, Department of } \\
\text { Pediatrics } \\
\text { Korppi, Matti; Kuopio University Hospital, Department of Pediatrics }\end{array}$ \\
\hline Keywords: & $\begin{array}{l}\text { child, spirometry, obstruction, overweight, obesity, lung function, } \\
\text { wheezing }\end{array}$ \\
\hline
\end{tabular}

\section{SCHOLARONE ${ }^{\text {m }}$ Manuscripts}




\title{
Lung function and overweight in school aged children after early childhood wheezing
}

Sidoroff Virpi ${ }^{1}$ MD, Hyvärinen Mari $\mathrm{K}^{2} \mathrm{MD}$, Piippo-Savolainen Eija ${ }^{2} \mathrm{MD}, \mathrm{PhD}$, Korppi Matti ${ }^{2,3} \mathrm{MD}, \mathrm{PhD}$, Prof

${ }^{1}$ University of Eastern Finland, School of Medicine, Department of Pediatrics, Kuopio, Finland

${ }^{2}$ Department of Pediatrics, Kuopio University Hospital, Kuopio, Finland

${ }^{3}$ Pediatric Research Center, Tampere University Hospital, Tampere, Finland

\section{Corresponding author:}

Sidoroff Virpi, Eteläkatu 10 b 7, 80110 Joensuu, Finland,

email: vpietika@hytti.uku.fi, tel +358-400015215

\begin{abstract}
Abbreviated title: Lung function and overweight in wheezy children
\end{abstract}




\section{Summary}

Background and purpose. Recently, obesity has been connected with wheezing, asthma and reduced lung function. Most previous studies have been cross-sectional. The aim of the present follow-up study was to evaluate the association of preceding or current overweight or obesity with lung function at early and late school age after early childhood wheezing.

Material and methods. From the 100 children hospitalized for infection associated wheezing at $<24$ months of age, 83 attended the control visit at 4.0 years, 82 at 7.2 years and 81 at 12.3 years of age. Flow-volume spirometry was performed in 79 children at 7.2 years and in 80 children at 12.3 years of age. The weight status was assessed by calculating body mass index (BMI) at all visits. Age- and gender-specific BMI standard deviation scores (BMI-SDS) of $>1.3 \mathrm{SD}$ and $>2.0 \mathrm{SD}$ were defined to mean overweight and obesity, respectively.

Results. Overweight at both 7.2 and 12.3 years of age was associated with decreased $\mathrm{FEV}_{1} / \mathrm{FVC}$ (forced expiratory volume in one second/ forced vital capacity). Overweight and obesity at 7.2 years of age were associated with decreased $\mathrm{FEV}_{1} / \mathrm{FVC}$ and $\mathrm{MEF}_{50}$ (maximal expiratory flow at $50 \%$ of FVC) at 12.3 years of age. The results were similar by continuous and categorized analyses, being robust to adjustments for viral findings during early childhood wheezing and asthma maintenance medication at school age. Conclusion. Overweight and obesity are significant risk factors for reduced lung function at school age after early childhood wheezing. Thus, early-life wheezers should avoid excessive weight gain during childhood. 
Keywords: child, spirometry, obstruction, overweight, obesity, lung function, wheezing
Abbreviations:
BMI body mass index
BMI-SDS body mass index standard deviation score
TLC total lung capacity
FRC functional residual capacity
FVC forced vital capacity
$\mathrm{FEV}_{1} \quad$ forced expiratory volume in one second
$\mathrm{FEV}_{1} / \mathrm{FVC}$ forced expiratory volume in one second/forced vital capacity
$\mathrm{MEF}_{50} \quad$ maximal expiratory flow at $50 \%$ of FVC
$\mathrm{MEF}_{25}$ maximal expiratory flow at $25 \%$ of FVC
aOR adjusted odds ratios
Cl confidence intervals
RSV respiratory syncytial virus 


\section{Introduction}

Asthma and overweight or obesity have increased concomitantly among both children and adults during the last three decades in western countries ${ }^{1-3}$. The studies have suggested an association between wheezing symptoms and obesity ${ }^{4-9}$, and also between asthma diagnoses and obesity ${ }^{10-13}$. When pulmonary function and bronchial reactivity have been studied objectively, the results have been mainly negative $\mathrm{e}^{5,14-18}$.

In adults, obesity decreases both lung volume, as documented by reduced total lung capacity (TLC), forced vital capacity (FVC) and functional residual capacity (FRC), and airway flows, as documented by decreased forced expiratory volume in one second $\left(\mathrm{FEV}_{1}\right)$ and increased airway resistance ${ }^{19,20}$. In addition, obesity leads to obstruction in peripheral airway ${ }^{21}$, as documented by decreased flows at $50 \%\left(\mathrm{MEF}_{50}\right)$ or at $25 \%$ $\left(\mathrm{MEF}_{25}\right)$ of FVC. However, the largest impact seems to target at expiratory reserve volume, which means that restriction is the characteristic lung function disorder in obesity ${ }^{22,23}$. In addition, weight reduction in obese adults elicited an improvement of lung function ${ }^{24}$.

In children with asthma suggestive symptoms, high body mass index (BMI) was associated with subnormal lung function in one study ${ }^{18}$, but not in two others ${ }^{4,5}$. In healthy children, lung function was either impaired ${ }^{25}$, improved in boys and girls ${ }^{26}$ or improved only in girls ${ }^{27}$ by excessive weight gain

We have prospectively followed-up a cohort of children hospitalized for infection associated wheezing at $<24$ months of age in 1992-1993. The weights and heights of the children were measured at follow-up visits at the median ages of 4.0, 7.2 and 12.3 years, and spirometry was performed at both visits at school age ${ }^{28-30}$. 
The aim of the present study was to evaluate the association between overweight or obesity and lung function at school age in former early-life wheezers, with a special focus on the influence of an emerging overweight.

2

3

4

5

6

7

8

9

10

11

12

13

14

15

16

17

18

19

20

21

22

23

24

25

26

27

28

29

30

31

32

33

34

35

36

37

38

39

40

41

42

43

44

45

46

47

48

49

50

51

52

53

54

55

56

57

58

59

60

John Wiley \& Sons, Inc. 


\section{Material and methods}

\section{Study design}

One-hundred consecutive children, hospitalized for wheezing associated respiratory infection at age 1-23 months, were recruited into this follow-up study in $1992-1993^{31}$. Maintenance therapy for asthma was one of the exclusion criteria, and the wheezing episode was the first one in $87 \%$ of the included children ${ }^{32}$. The basic data were collected by interviewing the parents during hospitalization using a structured questionnaire. Seven respiratory viruses, including respiratory syncytial virus (RSV), were studied by antigen and antibody assays ${ }^{32}$. Later, viral studies were supplemented by polymerase chain reaction to RSV and rhinoviruses in frozen samples ${ }^{33,34}$. In all, RSV was identified in $29 / 100$ and rhinovirus in $27 / 81$ cases $^{33,35}$.

Three follow-up visits were prospectively organized at the median ages of 4.0 years, 7.2 years and 12.3 years ${ }^{28-30}$. Asthma was present in 33/82 (40.2\%) children at the 7.2-year visit $^{29}$ and in $32 / 81(39.5 \%)$ children at the 12.3 -year visit ${ }^{30}$. Data on medical history, including the use of asthma medication during the preceding 12 months, were collected by interviewing the parents.

\section{Assessment of weight status}

The weights and heights of the children, measured by an experienced nurse using standard methods, were registered in all attending children at all controls visits. Body mass index (BMI) was calculated by using the equation: weight $(\mathrm{kg}) /[\text { height }(\mathrm{m})]^{2}$. Due to the lack of Finnish references, we applied British gender- and age-specific populationbased references. BMI standard deviation score (BMI-SDS), also called Z-score, was 
assessed by an obesity calculator (NIBHI 2007) ${ }^{36}$. This calculator applies British growth references from 1990, produced by the LMS method in $1995^{37,38}$, and revised in $1996^{39}$. The LMS method summarizes the distribution of BMI at each age by its median (M), coefficient of variation (S), and skewness expressed as a Box-Cox power (L) required to transform the data to normal ${ }^{40}$.

In the present study, we used the same cut-off points for overweight and obesity as proposed by the British study evaluating the limits of obesity and overweight in different populations $^{41}$. The cut-off point for overweight was BMI $>91$ percentile (approximating BMI-SDS >1.3) and for obesity BMI >98 percentile (approximating BMI-SDS >2.0) ${ }^{19,41}$. In the British population, these cut-off points corresponds BMI $25 \mathrm{~kg} / \mathrm{m}^{2}$ and BMI 30 $\mathrm{kg} / \mathrm{m}^{2}$ levels, respectively, in the 18 years old young adults ${ }^{41}$.

\section{Measurement of lung function}

Lung function was studied by flow-volume spirometer (FVS) (Medikro, Kuopio, Finland) at the 7.2-year and 12.3-year study visits. The parameters were expressed as percentages of the gender-specific height-related reference values (\% of predicted) for Finnish children ${ }^{42,44}$. The parameters registered were FVC (forced vital capacity), $\mathrm{FEV}_{1}$ (forced expiratory volume in one second), $\mathrm{FEV}_{1} / \mathrm{FVC}, \mathrm{MEF}_{50}$ (maximal expiratory flow at $50 \%$ of $\mathrm{FVC}$ ) and $\mathrm{MEF}_{25}$ (maximal expiratory flow at $25 \%$ of FVC). Either the measurement with the highest $\mathrm{FEV}_{1}$ (at the 7.2-year study) ${ }^{29}$ or the composite maximal curve (at the 12.3-year study) ${ }^{30}$ was in each child recorded for further analyses. The cut-off limits for abnormal values were $80 \%$ for $\mathrm{FEV}_{1}, 88 \%$ for $\mathrm{FEV}_{1} / \mathrm{FVC}, 62 \%$ for $\mathrm{MEF}_{50}$ and $48 \%$ for $\mathrm{MEF}_{25}{ }^{17,30,43}$. 
Lung function data were available from 79 children at the 7.2-year and from 81 children at the 12.3-year study visits. The numbers of children with anti-inflammatory maintenance medication for asthma during the 12 preceding months were $29 / 79(36.77 \%)$ at age of 7.2 years and $18 / 80(22.5 \%)$ at age of 12.3 years. At the 4.0 -year visit, weight status was assessed for 74 children with lung function data available at the 7.2-year visit.

\section{Statistics}

The data were analysed using SPSS 17.0 software (SPSS Inc. Chicago, IL, USA). MannWhitney U-test was used in univariate analyses and analysis of variance (ANOVA) in multivariate analyses for continuous FVS parameters. In the previous studies in this cohort, RSV etiology of wheezing in early childhood was associated with a nonreversible restrictive pattern of lung function and non-RSV etiology (mostly rhinovirus) with an increased asthma risk and a reversible obstructive pattern of lung function at school age ${ }^{43,44}$. Therefore, analyses by ANOVA were adjusted also for RSV etiology of wheezing in early childhood, in addition to adjustment with anti-inflammatory asthma medication during the preceding 12 months before the study visit at school age. Logistic regression analysis, adjusted for RSV etiology of early childhood wheezing and antiinflammatory asthma medication during the 12 preceding months before the study visit, was applied for categorized (by the limits of abnormal values in \% predicted) FVS parameters, and the results were expressed as adjusted odds ratios (aOR) and their $95 \%$ confidence intervals $(95 \% \mathrm{CI})$.

\section{Ethics}


The study was approved by the joint Research Ethics Committee of Kuopio University and Kuopio University Hospital. Informed written consent was obtained from the parents of the children. 


\section{Results}

Overweight was present in $6.0 \%$ of children at 4.0 years, in $22.2 \%$ at 7.3 years and in $33.3 \%$ at 12.3 years of age. Less than $4 \%$ of children were obese at 4.0 years of age. The proportion of obese children was $8.6 \%$ at 7.3 years and $19.8 \%$ at 12.3 years of age. Three of 5 overweight children at age 4.0 years were overweight at age 7.2 years, and all 3 obese children were obese, respectively. Fifteen of the 16 overweight children at age 7.2 years were overweight at age 12.3 years, and 4 of the 6 obese children were obese, respectively.

In univariate analyses at 7.2 years of age, the only significant association was between current overweight and lower $\mathrm{FEV}_{1} / \mathrm{FVC}$ (Table 1). There were no significant associations between previous (4.0 years of age) overweight or obesity and any FVS parameter at age 7.2 years (Data not shown). In multivariate analyses, the association between obesity and lower $\mathrm{FEV}_{1} / \mathrm{FVC}$ changed to significant (Table 1). All other associations between previous or current overweight or obesity and FVS remained as unchanged.

In univariate analyses at 12.3 years of age, previous ( 7.2 years of age) overweight was associated with lower $\mathrm{FEV}_{1} / \mathrm{FVC}$, and current (12.3 years of age) overweight was associated with lower $\mathrm{FEV}_{1} / \mathrm{FVC}, \mathrm{MEF}_{50}$ and $\mathrm{MEF}_{25}$ (Tables 2). Similarly, previous obesity was associated with lower $\mathrm{FEV}_{1} / \mathrm{FVC}$, and current obesity was associated with lower $\mathrm{FEV}_{1} / \mathrm{FVC}, \mathrm{MEF}_{50}$ and $\mathrm{MEF}_{25}$ (Table 3). In multivariate analyses, the association between current overweight and $\mathrm{MEF}_{50}$ changed to non-significant (Table 2). All other associations between previous or current overweight or obesity and FVS remained as unchanged. 
In the logistic regression analyses, both previous and current overweight were significant risk factors for $\mathrm{FEV}_{1} / \mathrm{FVC}<88 \%$ at both 7.2 years (Table 4 ) and at 12.3 years of age (Table 5). Since overweight was highly permanent from 4.0 to 7.3 years of age and from 7.2 to 12.3 years of age, respectively, previous and current overweight could not be incorporated as variables in the same model. Therefore, the design of the study did not allow to asses their influences separately. Current obesity was a significant risk factor for $\mathrm{FEV}_{1} / \mathrm{FVC}<88 \%(\mathrm{aOR} 8.07,95 \%$ CI $2.10-31.05)$ and for $\mathrm{MEF}_{25}<48 \%(\mathrm{aOR} 4.34,95 \%$ CI 1.06-17.79) at 12.3 years of age. 


\section{Discussion}

There are three main results in the present study. First, the number of overweight and obese children increased constantly by age during the follow-up after early childhood wheezing until the median age of 12.3 years. Finally, a third was overweight, and about $20 \%$ were obese. The figures are higher than those calculated from self-reported weights and heights in 12-18 years old Finnish children in 1999, when $16.7 \%$ of the boys and $9.8 \%$ of the girls were overweight, and $1.4 \%$ and $0.4 \%$ were obese, assessed by using age- and gender-related international reference values ${ }^{45}$. Second, current overweight was associated with decreased $\mathrm{FEV}_{1} / \mathrm{FVC}$ at both 7.2 and 12.3 years of age. Overweight children had also reduced flows in small airways by $\mathrm{MEF}_{25}$ and obese children by $\mathrm{MEF}_{25}$ and $\mathrm{MEF}_{50}$ at age 12.3 years. $\mathrm{FEV}_{1} / \mathrm{FVC}$ is considered as the most sensitive and reliable measure of obstruction, but the reliability of $\mathrm{MEF}_{25}$ has been questioned. Third, overweight and obesity at early school age preceded reduced $\mathrm{FEV}_{1} / \mathrm{FVC}$ at age 12.3 years. But, since overweight was highly permanent from early to late school age, the influences of previous and current overweight could not be assessed separately.

The association between excessive weight gain and reduced lung function has been well documented in adults ${ }^{14-16,20,22}$. In a Finnish study, weight reduction in obese adults even elicited an improvement of lung function ${ }^{24}$. The effect of excessive weight gain to lung function seems to depend on the degree of obesity and on the presence and severity of asthma. When lung function was studied in 52 non-asthmatic non-obese, in 53 asthmatic non-obese, in 52 obese non-asthmatic and in 53 asthmatic obese adults, lung function was reduced in patients with asthma and obesity, and in addition, FVC and FRC were reduced 
in obese adults also with no asthma ${ }^{16}$. In a birth cohort from New Zealand, an association was found between increasing BMI and decreasing $\mathrm{FEV}_{1} / \mathrm{FVC}$ in 9-26 years old females, but not in males ${ }^{15}$. In a study on difficult-to-treat asthma, $\mathrm{FEV}_{1}$ was increased and FRC and total lung capacity were decreased in obese patients ${ }^{46}$. Thus, controlled studies in adults with asthma ${ }^{16,46}$, as well as population-based studies in healthy adults ${ }^{15,22,23}$, highlight the connection between obesity and decreased expiratory reserve volumes, which means that restriction is the characteristic lung function disorder in obesity.

In a population study from China, overweight had a beneficial effect on lung function in 7 to 20 years old healthy girls ${ }^{27}$. In a population study from Mexico, lung function improved when weight increased in 8-11 years old healthy children, but after that age, lung function first reached a plateau and then decreased among the obese youths ${ }^{47}$. Lung function by spirometry was compared between 657 overweight and 196 normal weight Greek children, and $\mathrm{FVC}, \mathrm{FEV}_{1}, \mathrm{MEF}_{25-75 \%}$ and $\mathrm{FEV}_{1} / \mathrm{FVC}$ were reduced in overweight children ${ }^{18}$. In a population study from Australia, spirometry was performed in 2464 school children ${ }^{48}$. Height-related FVC and $\mathrm{FEV}_{1}$ increased by growth, but both FVC and $\mathrm{FEV}_{1}$ decreased in relation to increasing overweight. The result was opposite in an other Australian population study in 5993 children; all variables in the FVS were, irrespective of BMI, within normal limits, but $\mathrm{FEV}_{1}$ and $\mathrm{FVC}$ in the lowest BMI quintile were significantly lower than in other quintiles ${ }^{4}$. All these studies are cross-sectional with no follow-up available. The results seem confusing, but there may be following consistency; mild overweight may be beneficial but when substantial overweight or obesity develops, the effect turns to non-beneficial.

John Wiley \& Sons, Inc. 
The results of the present follow-up study after early childhood wheezing showed that overweight was associated with reduced $\mathrm{FEV}_{1} / \mathrm{FVC}$ at 7.2 and 12.3 years of age and reduced $\mathrm{MEF}_{50}$ and $\mathrm{MEF}_{25}$ at 12.3 years of age, in disagreement with most population studies in healthy children ${ }^{4,5,27,46,47}$. However, the associations may be different in children with asthma; about $40 \%$ of our patients had asthma and all had wheezed in early childhood. Lung function and weight status were studied as a part of the childhood asthma management program (CAMP) in 1041 American children aged 5-12 years ${ }^{49}$, and increasing BMI was associated with increasing $\mathrm{FEV}_{1}$ and $\mathrm{FVC}$, but decreasing $\mathrm{FEV}_{1} / \mathrm{FVC}$. The increase in $\mathrm{FVC}$ and decrease in $\mathrm{FEV}_{1} / \mathrm{FVC}$ are in accordance with the results of our present study. In the CAMP study, weight status and lung function were studied by a cross-sectional design at enrolment of the patients, and no follow-up data have been, at least thus far, published. We found no evidence for a restrictive pattern of lung function disorder in overweight or obese children, though suggested to be present in obese asthmatic adults ${ }^{15,16,22,23,46}$, and though was demonstrable after early childhood wheezing caused by RSV in 12.3 years old children of the present study ${ }^{43,44}$.

The mechanisms leading to lung function disorders in association with overweight or obesity may be narrowing of the small peripheral airways ${ }^{21}$, in line with decreased $\mathrm{MEF}_{50}$ and $\mathrm{MEF}_{25}$ values in the overweight and obese children at the 12.3-year visit of the present study. In addition, decreased compliance of either the lungs due to narrow peripheral airways or the chest wall due to body adiposity may lead to subnormal lung function, including both decreased airway flows which mean an obstructive lung function disorder and decreased lung volumes which means a restrictive lung function disorder ${ }^{48}$. The effect of excessive weight gain on lung function may be age-dependent, which 
means that different mechanisms may influence in children and in adults and in children at different ages. In a case-control study from Denmark, $\mathrm{FEV}_{1}$ and $\mathrm{FVC}$ were reduced in 193 obese men, compared with normal weight 215 controls, at 27 years of age, but after adjustments with current BMI, childhood BMI at 7 years of age was positively associated with both $\mathrm{FEV}_{1}$ and FVC ${ }^{50}$.

The strengths of the present study are the long, over 10 years prospective follow-up time and the fact that weights and heights of the children were measured at all control visits by experienced nurses using calibrated scales, thus allowing a reliable follow-up of the weight status of the children. Prospectively collected data on potential confounding factors, like data on viral etiology of early childhood wheezing and use of antiinflammatory medication at school age, were available for adjusted analyses. The small number of the patients is a remarkable limitation, and with no doubt, the study was underpowered to reveal all presenting associations. Our selected material, children hosptalized for wheezing at $<24$ months of age, can be considered as a weakness of the study lessening the generalizibility of the results. On the other hand, early childhood wheezers are at a high risk for later pulmonary disorders, and knowing the risk factors relevant in this specific group of children, like overweight and obesity according to the present results, opens new ways for preventive measures.

In conclusion, overweight and obesity increased constantly by age during follow-up after wheezing in early childhood until the median age of 12.3 years. Overweight at school age was associated with bronchial obstruction, as manifested by decreased $\mathrm{FEV}_{1} / \mathrm{FVC}$ at 7.2 years and 12.3 years of age, and also with decreased flows in small airways at 12.3 years 
of age. Our results stress the importance of the prevention of excessive weight gain at pre-school and school age in children with early childhood wheezing. 
Acknowledgements: We thank Vesa Kiviniemi, Ph.Lic., for statistical advice, Kuopio University Hospital, The National Foundation for Pediatric Research in Finland and Tampere Tuberculosis Foundation for financial support.

The authors do not have a financial relationship with any commercial entity that has an interest in the subjects of this manuscript. 


\section{References:}

1. Ford ES. The epidemiology of obesity and asthma. J Allergy Clin Immunol. 2005;115:.897-909.

2. Akinbami LJ, Schoendorf KC. Trends in childhood asthma: prevalence, health care utilization, and mortality. Pediatrics. 2002; 110: 315-322

3. Lobstein T, Frelut ML. Prevalence of overweight among children in Europe. Obes Rev. 2003; 4: 195-200.

4. Schachter LM, Peat JK, Salome CM. Asthma and atopy in overweight children. Thorax. 2003; 58: 1031-1035.

5. Bibi H, Shoseyov D, Feigenbaum D, Genis M, Friger M, Peled R, Sharff S. The relationship between asthma and obesity in children: is it real or a case of over diagnosis? J Asthma. 2004; 41: 403-410.

6. Wickens K, Barry D, Friezema A, Rhodius R, Bone N, Purdie G, Crane J. Obesity and asthma in 11-12 year old New Zealand children in 1989 and 2000. Thorax. 2005; 60: 712.

7. Mamun AA, Lawlor DA, Alati R, O’Callaghan MJ, Williams GM, Najman JM.

Increasing body mass index from age 5 to 14 years predicts asthma among adolescents: evidence from a birth cohort study: Intern J Obes. 2007; 31; 578-583

8. Joseph CLM, Havstad SL, Ownby DR, Zoratti E, Peterson EL, Stringer S, Johnson CC. Gender differences in the association of overweight and asthma morbidity among urban adolescents with asthma. Pediatr Allergy Immunol. 2009: 20: 362-369. 


\author{
9. Kusunoki T, Morimoto T, Nishikomori R, Heike T, Ito M, Hosoi S, Nakahata T. \\ Obesity and the prevalence of allergic diseases in schoolchildren. Pediatr Allergy \\ Immunol. 2008: 19:527-534.
}

10. Gilliland FD, Berhane K, Islam T, McConnell R, Gauderman WJ, Gilliland SS, Avol

E, Peters J. Obesity and the risk of newly diagnosed asthma in school-age children. Am J Epidemiol. 2003; 158: 406-415.

11. Gold DR, Damokosh AI, Dockery DW, Berkey CS. Body-mass index

as a predictor of incident asthma in a prospective cohort of children.

Pediatr Pulmonol. 2003; 36: 514-521.

12. Mannino DM, Mott J, Ferdinands JM, Camargo CA, Friedman M, Greves HM Redd

SC. Boys with high body masses have an increased risk of developing asthma: findings

from the National Longitudinal Survey of Youth (NLSY). Intern J Obes (Lond). 2006;

30: 6-13.

13. Jartti T, Saarikoski L, Jartti L, LIsinen I, Jula A, Huupponen R, Viikari J, Raitakari

OT. Obesity, adopokines and asthma. Allergy. 2009; 64: 770-777.

14. Schachter LM, Salome CM, Peat JK, Woolcock AJ. Obesity is a risk for asthma and wheeze but not airway hyper-responsiveness. Thorax. 2001; 56: 4-8.

15. Hancox RJ, Milne BJ, Poulton R, Taylor DR, Greene JM, McLachlan CR, Cowan JO, Flannery EM, Herbison GP, Sears MR. Sex differences in the relation between body mass index and asthma and atopy in a birth cohort. Am J Respir Crit Care Med. 2005; 171: 440-445. 


\author{
16. Nicolacakis K, Skowronski ME, Coreno AJ, West E, Nader NZ, Smith RL, \\ McFadden ER. Observevation on the physiological interactions between obesity and \\ asthma. J Appl Physiol. 2008: 105: 1533-1541.
}
17. Viljanen A, Halttunen P, Kreus K, Viljanen BC: Spirometric studies in non-smoking healthy adults. Scand J Clin Lab Invest. 1982; 159 (Suppl): 5-20.

18. Spathopoulos D, Paraskakis E, Trypsianis G,Tsalkidis A, Arvanitidou V, Emporiadou M, Bouros D, Chatzimichael A. The Effect of Obesity on Pulmonary Lung Function of School Aged Children in Greece. Pediatr Pulmon. 2009: 44: 273-280.

19. Deane S, Thomson A. Obesity and pulmonologist. Review. Arch Dis Child. 2006; 91: 188-191.

20. Sin DD, Sutherland ER. Obesity and the lung: 4 obesity and asthma. Thorax 2008; 63: 1018-1023.

21. Rubinstein I, Zamel N, DuBarry L, Hoffstein MD. Airflow limitation in morbidly obese, nonsmoking men. Ann Intern Med. 1990; 112: 828-832.

22. Jones RL, Nzekwu MMU. The effects of body mass index on lung volumes. Chest. $2006 ; 130: .827-833$.

23. Sin DD, Jones RL, Man SFP. Obesity is a risk factor for dyspnea but not for airflow obstruction. Arch Intern Med. 2002; 162: 1477-1481.

24. Stenius-Aarniala B, Pousa T, Kvarnström J. Grönlund E-L, Ylikahri M, Mustajoki P. Immediate and long term effects of weight reduction in obese people with asthma: randomized controlled study. BMJ. 2000; 320: 827-832 
25. Li AM, Chan D, Wong E, Yin J, Nelson EAS, Fok TF. The effect of obesity on pulmonary function. Arch Dis Child 2003; 88: 361-363.

26. He Q, Qong T, Du L, Jiang Z, Qui H, Gao Y, Liu J, Wu J, Yu IT . Respiratory Health in overweight and obese chinese children. Pediatr Pulmonol. 2009: 44: 997-1002

27. Fung KP, Lau SP, Chow OKW, Lee J, Wong TW. Effect of overweight on lung function. Arch Dis Child. 1990; 65: 512-515.

28. Reijonen TM, Kotaniemi-Syrjanen A, Korhonen K, Korppi M. Predictors of asthma three years after hospital admission for wheezing in infancy. Pediatrics. 2000; 106: 14061412

29. Kotaniemi-Syrjänen A, Reijonen TM, Korhonen K, Korppi M. Wheezing requiring hospitalization in early childhood: predictive factors for asthma in a six-year follow-up. Pediatr Allergy Immunol. 2002; 13: 418-425.

30. Hyvärinen MK, Kotaniemi-Syrjänen A, Reijonen TM, Korhonen K, Korppi MO. Teenage asthma after severe early childhood wheezing: an 11-year prospective followup. Pediatr Pulmonol. 2005; 40: 316-323.

31. Reijonen T, Korppi M, Kuikka L, Remes K. Anti-inflammatory therapy reduces wheezing after bronchiolitis. Arch Pediatr Adolesc Med. 1996; 150: 512-517.

32. Reijonen TM, Korppi M. One-year follow-up of young children hospitalized for wheezing: the influence of early anti-inflammatory therapy and risk factors for subsequent wheezing and asthma. Pediatr Pulmonol. 1998; 26: 113-119.

John Wiley \& Sons, Inc. 
33. Kotaniemi-Syrjänen A, Vainionpaa R, Reijonen TM, Waris M, Korhonen K, Korppi

M. Rhinovirus-induced wheezing in infancy--the first sign of childhood asthma? J Allergy Clin Immunol. 2003; 11: 66-71.

34. Korppi M, Kotaniemi-Syrjanen A, Waris M, Vainionpaa R, Reijonen TM. Rhinovirus-associated wheezing in infancy: comparison with respiratory syncytial virus bronchiolitis. Pediatr Infect Dis J. 2004; 23: 995-999.

35. Kotaniemi-Syrjänen, Laatikainen A, Waris M, Reijonen T, Vainionpää R, Korppi M. Respiratory syncytial virus infection in children hospitalized for wheezing: Virus-specific studies from infancy to preschool years. Acta Paediatr. 2005; 94: 159-164.

36. Northwest Institute for Bio-Health Informatics. Child obesity calculator using British 1990 growth reference data. Available at: http://www.phsim.man.ac.uk/. Accessed January 18, 2007.

37. Cole TJ, Freeman JV, Preece MA. Body mass index reference curves for the UK, 1990. Arch Dis Child. 1995; 73: 25-29.

38. Freeman JV, Cole TJ, Chinn S, Jones PR, White EM, Preece MA. Cross sectional stature and weight reference curves for the UK, 1990. Arch Dis Child 1995; 73: 17-24.

39. Cole TJ, Freeman JV, Preece MA. British 1990 growth reference centiles for weight, height, body mass index and head circumference fitted by maximum penalized likelihood. Stat Med 1998; 17: 407-429

40. Cole TJ. The LMS method for constructing normalized growth standards. Eur J Clin Nutr 1990; 44: 45-60. 
41. Cole TJ, Bellizzi MC, Flegal KM, Dietz WH. Establishing a standard definition for child overweight and obesity worldwide: international survey. Brit Med J 2000; 320: $1240-1246$.

42. Koillinen H, Wanne O, Niemi V, Laakkonen E. Reference values for flow-volume spirometry and peak expiratory flow rates in healthy Finnish children. Finnish Medical Journal 1998; 5: 395-402. (in Finnish).

43. Kotaniemi-Syrjänen A, Reijonen TM, Korhonen K, Waris M, Vainionpää R, Korppi M. Wheezing due to rhinovirus infection in infancy: Bronchial hyperresponsiveness at school age. Pediatr Internat. 2008: 50;.506-510.

44. Hyvärinen MK, Kotaniemi-Syrjänen A, Reijonen T, Korhonen K, Korppi M. Lung function and bronchial hyper-responsiveness 11 years after hospitalization for chonchiolitis. Acta Paeditr. 2007; 96: 1464-1469.

45. Kautiainen S, Rimpelä A, Vikat A, Virtanen SM. Secular trends in overweight and obesity among Finnish adolescents in 1977-1999. Int J Obes Relat Metab Disord. 2002; 26: $544-52$.

46. van Veen IH, Ten Brinke A, Sterk PJ, Rabe KF, Bel EH. Airway inflammation in obese and non-obese patients with difficult-to-treat asthma. Allergy. 2008; 63: 570-574.

47. Peres-Padilla R, Rojas R, Torres V, Borja-Aburto V, Olaiz G. Obesity among Children Residing in Mexico City and its Impact on Lung Function: A Comparison with Mexican-Americans. Arch Med Res. 2006; 156-171.

John Wiley \& Sons, Inc. 
48. Lazarus R, Colditz G, Berkey C, Speizer F. Effects of body fat on ventilatory function in children and adolecents: cross-sectional findings from a random population sample of school children. Pediatr Pulmon. 1997; 24: 187-194.

49. Tantisira KG, Litonjua AA, Weiss ST, Fuhlbrigge AL (Childhood asthma

management program research group). Association of body mass with pulmonary

function in the childhood asthma management program (CAMP). Thorax. 2003; 58:

1036-1041.

50. Bua J, Prescott E, Schack-Nielsen L, Petersen L, Godtfredsen NS, Sørensen TI, Osler M. Weight history from birth through childhood and youth in relation to adult lung function, in Danish juvenile obese and non-obese men. Int J Obes (Lond). 2005; 29: 1055-1062.

John Wiley \& Sons, Inc. 


\title{
Lung function and overweight in school aged children after early childhood wheezing
}

Sidoroff Virpi ${ }^{1}$ MD, Hyvärinen Mari $\mathrm{K}^{2} \mathrm{MD}$, Piippo-Savolainen Eija ${ }^{2} \mathrm{MD}, \mathrm{PhD}$, Korppi Matti ${ }^{2,3} \mathrm{MD}, \mathrm{PhD}$, Prof

${ }^{1}$ University of Eastern Finland, School of Medicine, Department of Pediatrics, Kuopio, Finland

${ }^{2}$ Department of Pediatrics, Kuopio University Hospital, Kuopio, Finland

${ }^{3}$ Pediatric Research Center, Tampere University Hospital, Tampere, Finland

\section{Corresponding author:}

Sidoroff Virpi, Eteläkatu 10 b 7, 80110 Joensuu, Finland,

email: vpietika@hytti.uku.fi, tel +358-400015215

\begin{abstract}
Abbreviated title: Lung function and overweight in wheezy children
\end{abstract}




\section{Summary}

Background and purpose. Recently, obesity has been connected with wheezing, asthma and reduced lung function. Most previous studies have been cross-sectional. The aim of the present follow-up study was to evaluate the association of preceding or current overweight or obesity with lung function at early and late school age after early childhood wheezing.

Material and methods. From the 100 children hospitalized for infection associated wheezing at $<24$ months of age, 83 attended the control visit at 4.0 years, 82 at 7.2 years and 81 at 12.3 years of age. Flow-volume spirometry was performed in 79 children at 7.2 years and in 80 children at 12.3 years of age. The weight status was assessed by calculating body mass index (BMI) at all visits. Age- and gender-specific BMI standard deviation scores (BMI-SDS) of $>1.3 \mathrm{SD}$ and $>2.0 \mathrm{SD}$ were defined to mean overweight and obesity, respectively.

Results. Overweight at both 7.2 and 12.3 years of age was associated with decreased $\mathrm{FEV}_{1} / \mathrm{FVC}$ (forced expiratory volume in one second/ forced vital capacity). Overweight and obesity at 7.2 years of age were associated with decreased $\mathrm{FEV}_{1} / \mathrm{FVC}$ and $\mathrm{MEF}_{50}$ (maximal expiratory flow at $50 \%$ of FVC) at 12.3 years of age. The results were similar by continuous and categorized analyses, being robust to adjustments for viral findings during early childhood wheezing and asthma maintenance medication at school age. Conclusion. Overweight and obesity are significant risk factors for reduced lung function at school age after early childhood wheezing. Thus, early-life wheezers should avoid excessive weight gain during childhood. 
Keywords: child, spirometry, obstruction, overweight, obesity, lung function, wheezing
Abbreviations:
BMI body mass index
BMI-SDS body mass index standard deviation score
TLC total lung capacity
FRC functional residual capacity
FVC forced vital capacity
$\mathrm{FEV}_{1} \quad$ forced expiratory volume in one second
$\mathrm{FEV}_{1} / \mathrm{FVC}$ forced expiratory volume in one second/forced vital capacity
$\mathrm{MEF}_{50}$ maximal expiratory flow at $50 \%$ of FVC
$\mathrm{MEF}_{25}$ maximal expiratory flow at $25 \%$ of FVC
aOR adjusted odds ratios
$\mathrm{Cl} \quad$ confidence intervals
RSV respiratory syncytial virus 


\section{Introduction}

Asthma and overweight or obesity have increased concomitantly among both children and adults during the last three decades in western countries ${ }^{1-3}$. The studies have suggested an association between wheezing symptoms and obesity ${ }^{4-9}$, and also between asthma diagnoses and obesity ${ }^{10-13}$. When pulmonary function and bronchial reactivity have been studied objectively, the results have been mainly negative $\mathrm{e}^{5,14-18}$.

In adults, obesity decreases both lung volume, as documented by reduced total lung capacity (TLC), forced vital capacity (FVC) and functional residual capacity (FRC), and airway flows, as documented by decreased forced expiratory volume in one second $\left(\mathrm{FEV}_{1}\right)$ and increased airway resistance ${ }^{19,20}$. In addition, obesity leads to obstruction in peripheral airway ${ }^{21}$, as documented by decreased flows at $50 \%\left(\mathrm{MEF}_{50}\right)$ or at $25 \%$ $\left(\mathrm{MEF}_{25}\right)$ of FVC. However, the largest impact seems to target at expiratory reserve volume, which means that restriction is the characteristic lung function disorder in obesity $^{22,23}$. In addition, weight reduction in obese adults elicited an improvement of lung function ${ }^{24}$.

In children with asthma suggestive symptoms, high body mass index (BMI) was associated with subnormal lung function in one study ${ }^{18}$, but not in two others ${ }^{4,5}$. In healthy children, lung function was either impaired ${ }^{25}$, improved in boys and girls ${ }^{26}$ or improved only in girls ${ }^{27}$ by excessive weight gain

We have prospectively followed-up a cohort of children hospitalized for infection associated wheezing at $<24$ months of age in 1992-1993. The weights and heights of the children were measured at follow-up visits at the median ages of 4.0, 7.2 and 12.3 years, and spirometry was performed at both visits at school age ${ }^{28-30}$. 
The aim of the present study was to evaluate the association between overweight or obesity and lung function at school age in former early-life wheezers, with a special focus on the influence of an emerging overweight.

John Wiley \& Sons, Inc. 


\section{Material and methods}

\section{Study design}

One-hundred consecutive children, hospitalized for wheezing associated respiratory infection at age 1-23 months, were recruited into this follow-up study in $1992-1993^{31}$. Maintenance therapy for asthma was one of the exclusion criteria, and the wheezing episode was the first one in $87 \%$ of the included children ${ }^{32}$. The basic data were collected by interviewing the parents during hospitalization using a structured questionnaire. Seven respiratory viruses, including respiratory syncytial virus (RSV), were studied by antigen and antibody assays ${ }^{32}$. Later, viral studies were supplemented by polymerase chain reaction to RSV and rhinoviruses in frozen samples ${ }^{33,34}$. In all, RSV was identified in $29 / 100$ and rhinovirus in $27 / 81$ cases $^{33,35}$.

Three follow-up visits were prospectively organized at the median ages of 4.0 years, 7.2 years and 12.3 years ${ }^{28-30 .}$ Asthma was present in 33/82 (40.2\%) children at the 7.2-year visit $^{29}$ and in $32 / 81(39.5 \%)$ children at the 12.3 -year visit ${ }^{30}$. Data on medical history, including the use of asthma medication during the preceding 12 months, were collected by interviewing the parents.

\section{Assessment of weight status}

The weights and heights of the children, measured by an experienced nurse using standard methods, were registered in all attending children at all controls visits. Body mass index (BMI) was calculated by using the equation: weight $(\mathrm{kg}) /[\text { height }(\mathrm{m})]^{2}$. Due to the lack of Finnish references, we applied British gender- and age-specific populationbased references. BMI standard deviation score (BMI-SDS), also called Z-score, was 
assessed by an obesity calculator (NIBHI 2007) ${ }^{36}$. This calculator applies British growth references from 1990, produced by the LMS method in $1995^{37,38}$, and revised in $1996^{39}$. The LMS method summarizes the distribution of BMI at each age by its median (M), coefficient of variation (S), and skewness expressed as a Box-Cox power (L) required to transform the data to normal ${ }^{40}$.

In the present study, we used the same cut-off points for overweight and obesity as proposed by the British study evaluating the limits of obesity and overweight in different populations ${ }^{41}$. The cut-off point for overweight was BMI $>91$ percentile (approximating BMI-SDS >1.3) and for obesity BMI >98 percentile (approximating BMI-SDS >2.0) ${ }^{19,41}$. In the British population, these cut-off points corresponds BMI $25 \mathrm{~kg} / \mathrm{m}^{2}$ and BMI 30 $\mathrm{kg} / \mathrm{m}^{2}$ levels, respectively, in the 18 years old young adults ${ }^{41}$.

\section{Measurement of lung function}

Lung function was studied by flow-volume spirometer (FVS) (Medikro, Kuopio, Finland) at the 7.2-year and 12.3-year study visits. The parameters were expressed as percentages of the gender-specific height-related reference values (\% of predicted) for Finnish children ${ }^{42,44}$. The parameters registered were FVC (forced vital capacity), $\mathrm{FEV}_{1}$ (forced expiratory volume in one second), $\mathrm{FEV}_{1} / \mathrm{FVC}, \mathrm{MEF}_{50}$ (maximal expiratory flow at $50 \%$ of $\mathrm{FVC}$ ) and $\mathrm{MEF}_{25}$ (maximal expiratory flow at $25 \%$ of FVC). Either the measurement with the highest $\mathrm{FEV}_{1}$ (at the 7.2-year study) ${ }^{29}$ or the composite maximal curve (at the 12.3-year study) ${ }^{30}$ was in each child recorded for further analyses. The cut-off limits for abnormal values were $80 \%$ for $\mathrm{FEV}_{1}, 88 \%$ for $\mathrm{FEV}_{1} / \mathrm{FVC}, 62 \%$ for $\mathrm{MEF}_{50}$ and $48 \%$ for $\mathrm{MEF}_{25}{ }^{17,30,43}$. 
Lung function data were available from 79 children at the 7.2-year and from 81 children at the 12.3-year study visits. The numbers of children with anti-inflammatory maintenance medication for asthma during the 12 preceding months were $29 / 79(36.77 \%)$ at age of 7.2 years and $18 / 80(22.5 \%)$ at age of 12.3 years. At the 4.0 -year visit, weight status was assessed for 74 children with lung function data available at the 7.2-year visit.

\section{Statistics}

The data were analysed using SPSS 17.0 software (SPSS Inc. Chicago, IL, USA). MannWhitney U-test was used in univariate analyses and analysis of variance (ANOVA) in multivariate analyses for continuous FVS parameters. In the previous studies in this cohort, RSV etiology of wheezing in early childhood was associated with a nonreversible restrictive pattern of lung function and non-RSV etiology (mostly rhinovirus) with an increased asthma risk and a reversible obstructive pattern of lung function at school age ${ }^{43,44}$. Therefore, analyses by ANOVA were adjusted also for RSV etiology of wheezing in early childhood, in addition to adjustment with anti-inflammatory asthma medication during the preceding 12 months before the study visit at school age. Logistic regression analysis, adjusted for RSV etiology of early childhood wheezing and antiinflammatory asthma medication during the 12 preceding months before the study visit, was applied for categorized (by the limits of abnormal values in \% predicted) FVS parameters, and the results were expressed as adjusted odds ratios (aOR) and their $95 \%$ confidence intervals $(95 \% \mathrm{CI})$.

\section{Ethics}


The study was approved by the joint Research Ethics Committee of Kuopio University and Kuopio University Hospital. Informed written consent was obtained from the parents of the children. 


\section{Results}

Overweight was present in $6.0 \%$ of children at 4.0 years, in $22.2 \%$ at 7.3 years and in $33.3 \%$ at 12.3 years of age. Less than $4 \%$ of children were obese at 4.0 years of age. The proportion of obese children was $8.6 \%$ at 7.3 years and $19.8 \%$ at 12.3 years of age. Three of 5 overweight children at age 4.0 years were overweight at age 7.2 years, and all 3 obese children were obese, respectively. Fifteen of the 16 overweight children at age 7.2 years were overweight at age 12.3 years, and 4 of the 6 obese children were obese, respectively.

In univariate analyses at 7.2 years of age, the only significant association was between current overweight and lower $\mathrm{FEV}_{1} / \mathrm{FVC}$ (Table 1). There were no significant associations between previous (4.0 years of age) overweight or obesity and any FVS parameter at age 7.2 years (Data not shown). In multivariate analyses, the association between obesity and lower $\mathrm{FEV}_{1} / \mathrm{FVC}$ changed to significant (Table 1). All other associations between previous or current overweight or obesity and FVS remained as unchanged.

In univariate analyses at 12.3 years of age, previous ( 7.2 years of age) overweight was associated with lower $\mathrm{FEV}_{1} / \mathrm{FVC}$, and current (12.3 years of age) overweight was associated with lower $\mathrm{FEV}_{1} / \mathrm{FVC}, \mathrm{MEF}_{50}$ and $\mathrm{MEF}_{25}$ (Tables 2). Similarly, previous obesity was associated with lower $\mathrm{FEV}_{1} / \mathrm{FVC}$, and current obesity was associated with lower $\mathrm{FEV}_{1} / \mathrm{FVC}, \mathrm{MEF}_{50}$ and $\mathrm{MEF}_{25}$ (Table 3). In multivariate analyses, the association between current overweight and $\mathrm{MEF}_{50}$ changed to non-significant (Table 2). All other associations between previous or current overweight or obesity and FVS remained as unchanged. 
In the logistic regression analyses, both previous and current overweight were significant risk factors for $\mathrm{FEV}_{1} / \mathrm{FVC}<88 \%$ at both 7.2 years (Table 4 ) and at 12.3 years of age (Table 5). Since overweight was highly permanent from 4.0 to 7.3 years of age and from 7.2 to 12.3 years of age, respectively, previous and current overweight could not be incorporated as variables in the same model. Therefore, the design of the study did not allow to asses their influences separately. Current obesity was a significant risk factor for $\mathrm{FEV}_{1} / \mathrm{FVC}<88 \%(\mathrm{aOR} 8.07,95 \%$ CI $2.10-31.05)$ and for $\mathrm{MEF}_{25}<48 \%(\mathrm{aOR} 4.34,95 \%$ CI 1.06-17.79) at 12.3 years of age. 


\section{Discussion}

There are three main results in the present study. First, the number of overweight and obese children increased constantly by age during the follow-up after early childhood wheezing until the median age of 12.3 years. Finally, a third was overweight, and about $20 \%$ were obese. The figures are higher than those calculated from self-reported weights and heights in 12-18 years old Finnish children in 1999, when $16.7 \%$ of the boys and $9.8 \%$ of the girls were overweight, and $1.4 \%$ and $0.4 \%$ were obese, assessed by using age- and gender-related international reference values ${ }^{45}$. Second, current overweight was associated with decreased $\mathrm{FEV}_{1} / \mathrm{FVC}$ at both 7.2 and 12.3 years of age. Overweight children had also reduced flows in small airways by $\mathrm{MEF}_{25}$ and obese children by $\mathrm{MEF}_{25}$ and $\mathrm{MEF}_{50}$ at age 12.3 years. $\mathrm{FEV}_{1} / \mathrm{FVC}$ is considered as the most sensitive and reliable measure of obstruction, but the reliability of $\mathrm{MEF}_{25}$ has been questioned. Third, overweight and obesity at early school age preceded reduced $\mathrm{FEV}_{1} / \mathrm{FVC}$ at age 12.3 years. But, since overweight was highly permanent from early to late school age, the influences of previous and current overweight could not be assessed separately.

The association between excessive weight gain and reduced lung function has been well documented in adults ${ }^{14-16,20,22}$. In a Finnish study, weight reduction in obese adults even elicited an improvement of lung function ${ }^{24}$. The effect of excessive weight gain to lung function seems to depend on the degree of obesity and on the presence and severity of asthma. When lung function was studied in 52 non-asthmatic non-obese, in 53 asthmatic non-obese, in 52 obese non-asthmatic and in 53 asthmatic obese adults, lung function was reduced in patients with asthma and obesity, and in addition, FVC and FRC were reduced 
in obese adults also with no asthma ${ }^{16}$. In a birth cohort from New Zealand, an association was found between increasing BMI and decreasing $\mathrm{FEV}_{1} / \mathrm{FVC}$ in 9-26 years old females, but not in males ${ }^{15}$. In a study on difficult-to-treat asthma, $\mathrm{FEV}_{1}$ was increased and FRC and total lung capacity were decreased in obese patients ${ }^{46}$. Thus, controlled studies in adults with asthma ${ }^{16,46}$, as well as population-based studies in healthy adults ${ }^{15,22,23}$, highlight the connection between obesity and decreased expiratory reserve volumes, which means that restriction is the characteristic lung function disorder in obesity.

In a population study from China, overweight had a beneficial effect on lung function in 7 to 20 years old healthy girls ${ }^{27}$. In a population study from Mexico, lung function improved when weight increased in 8-11 years old healthy children, but after that age, lung function first reached a plateau and then decreased among the obese youths ${ }^{47}$. Lung function by spirometry was compared between 657 overweight and 196 normal weight Greek children, and $\mathrm{FVC}, \mathrm{FEV}_{1}, \mathrm{MEF}_{25-75 \%}$ and $\mathrm{FEV}_{1} / \mathrm{FVC}$ were reduced in overweight children ${ }^{18}$. In a population study from Australia, spirometry was performed in 2464 school children ${ }^{48}$. Height-related FVC and $\mathrm{FEV}_{1}$ increased by growth, but both FVC and $\mathrm{FEV}_{1}$ decreased in relation to increasing overweight. The result was opposite in an other Australian population study in 5993 children; all variables in the FVS were, irrespective of BMI, within normal limits, but $\mathrm{FEV}_{1}$ and $\mathrm{FVC}$ in the lowest BMI quintile were significantly lower than in other quintiles ${ }^{4}$. All these studies are cross-sectional with no follow-up available. The results seem confusing, but there may be following consistency; mild overweight may be beneficial but when substantial overweight or obesity develops, the effect turns to non-beneficial. 
The results of the present follow-up study after early childhood wheezing showed that overweight was associated with reduced $\mathrm{FEV}_{1} / \mathrm{FVC}$ at 7.2 and 12.3 years of age and reduced $\mathrm{MEF}_{50}$ and $\mathrm{MEF}_{25}$ at 12.3 years of age, in disagreement with most population studies in healthy children ${ }^{4,5,27,46,47}$. However, the associations may be different in children with asthma; about $40 \%$ of our patients had asthma and all had wheezed in early childhood. Lung function and weight status were studied as a part of the childhood asthma management program (CAMP) in 1041 American children aged 5-12 years ${ }^{49}$, and increasing BMI was associated with increasing $\mathrm{FEV}_{1}$ and $\mathrm{FVC}$, but decreasing $\mathrm{FEV}_{1} / \mathrm{FVC}$. The increase in $\mathrm{FVC}$ and decrease in $\mathrm{FEV}_{1} / \mathrm{FVC}$ are in accordance with the results of our present study. In the CAMP study, weight status and lung function were studied by a cross-sectional design at enrolment of the patients, and no follow-up data have been, at least thus far, published. We found no evidence for a restrictive pattern of lung function disorder in overweight or obese children, though suggested to be present in obese asthmatic adults ${ }^{15,16,22,23,46}$, and though was demonstrable after early childhood wheezing caused by RSV in 12.3 years old children of the present study ${ }^{43,44}$.

The mechanisms leading to lung function disorders in association with overweight or obesity may be narrowing of the small peripheral airways ${ }^{21}$, in line with decreased $\mathrm{MEF}_{50}$ and $\mathrm{MEF}_{25}$ values in the overweight and obese children at the 12.3-year visit of the present study. In addition, decreased compliance of either the lungs due to narrow peripheral airways or the chest wall due to body adiposity may lead to subnormal lung function, including both decreased airway flows which mean an obstructive lung function disorder and decreased lung volumes which means a restrictive lung function disorder ${ }^{48}$. The effect of excessive weight gain on lung function may be age-dependent, which 
means that different mechanisms may influence in children and in adults and in children at different ages. In a case-control study from Denmark, $\mathrm{FEV}_{1}$ and $\mathrm{FVC}$ were reduced in 193 obese men, compared with normal weight 215 controls, at 27 years of age, but after adjustments with current BMI, childhood BMI at 7 years of age was positively associated with both $\mathrm{FEV}_{1}$ and FVC ${ }^{50}$.

The strengths of the present study are the long, over 10 years prospective follow-up time and the fact that weights and heights of the children were measured at all control visits by experienced nurses using calibrated scales, thus allowing a reliable follow-up of the weight status of the children. Prospectively collected data on potential confounding factors, like data on viral etiology of early childhood wheezing and use of antiinflammatory medication at school age, were available for adjusted analyses. The small number of the patients is a remarkable limitation, and with no doubt, the study was underpowered to reveal all presenting associations. Our selected material, children hosptalized for wheezing at $<24$ months of age, can be considered as a weakness of the study lessening the generalizibility of the results. On the other hand, early childhood wheezers are at a high risk for later pulmonary disorders, and knowing the risk factors relevant in this specific group of children, like overweight and obesity according to the present results, opens new ways for preventive measures.

In conclusion, overweight and obesity increased constantly by age during follow-up after wheezing in early childhood until the median age of 12.3 years. Overweight at school age was associated with bronchial obstruction, as manifested by decreased $\mathrm{FEV}_{1} / \mathrm{FVC}$ at 7.2 years and 12.3 years of age, and also with decreased flows in small airways at 12.3 years 
of age. Our results stress the importance of the prevention of excessive weight gain at pre-school and school age in children with early childhood wheezing. 
Acknowledgements: We thank Vesa Kiviniemi, Ph.Lic., for statistical advice, Kuopio University Hospital, The National Foundation for Pediatric Research in Finland and Tampere Tuberculosis Foundation for financial support.

The authors do not have a financial relationship with any commercial entity that has an interest in the subjects of this manuscript. 


\section{References:}

1. Ford ES. The epidemiology of obesity and asthma. J Allergy Clin Immunol. 2005;115:.897-909.

2. Akinbami LJ, Schoendorf KC. Trends in childhood asthma: prevalence, health care utilization, and mortality. Pediatrics. 2002; 110: 315-322

3. Lobstein T, Frelut ML. Prevalence of overweight among children in Europe. Obes Rev. 2003; 4: 195-200.

4. Schachter LM, Peat JK, Salome CM. Asthma and atopy in overweight children. Thorax. 2003; 58: 1031-1035.

5. Bibi H, Shoseyov D, Feigenbaum D, Genis M, Friger M, Peled R, Sharff S. The relationship between asthma and obesity in children: is it real or a case of over diagnosis? J Asthma. 2004; 41: 403-410.

6. Wickens K, Barry D, Friezema A, Rhodius R, Bone N, Purdie G, Crane J. Obesity and asthma in 11-12 year old New Zealand children in 1989 and 2000. Thorax. 2005; 60: 712.

7. Mamun AA, Lawlor DA, Alati R, O’Callaghan MJ, Williams GM, Najman JM.

Increasing body mass index from age 5 to 14 years predicts asthma among adolescents: evidence from a birth cohort study: Intern J Obes. 2007; 31; 578-583

8. Joseph CLM, Havstad SL, Ownby DR, Zoratti E, Peterson EL, Stringer S, Johnson CC. Gender differences in the association of overweight and asthma morbidity among urban adolescents with asthma. Pediatr Allergy Immunol. 2009: 20: 362-369. 
9. Kusunoki T, Morimoto T, Nishikomori R, Heike T, Ito M, Hosoi S, Nakahata T.

Obesity and the prevalence of allergic diseases in schoolchildren. Pediatr Allergy

Immunol. 2008: 19:527-534.

10. Gilliland FD, Berhane K, Islam T, McConnell R, Gauderman WJ, Gilliland SS, Avol

E, Peters J. Obesity and the risk of newly diagnosed asthma in school-age children. Am J Epidemiol. 2003; 158: 406-415.

11. Gold DR, Damokosh AI, Dockery DW, Berkey CS. Body-mass index as a predictor of incident asthma in a prospective cohort of children.

Pediatr Pulmonol. 2003; 36: 514-521.

12. Mannino DM, Mott J, Ferdinands JM, Camargo CA, Friedman M, Greves HM Redd SC. Boys with high body masses have an increased risk of developing asthma: findings from the National Longitudinal Survey of Youth (NLSY). Intern J Obes (Lond). 2006; 30: 6-13.

13. Jartti T, Saarikoski L, Jartti L, LIsinen I, Jula A, Huupponen R, Viikari J, Raitakari OT. Obesity, adopokines and asthma. Allergy. 2009; 64: 770-777.

14. Schachter LM, Salome CM, Peat JK, Woolcock AJ. Obesity is a risk for asthma and wheeze but not airway hyper-responsiveness. Thorax. 2001; 56: 4-8.

15. Hancox RJ, Milne BJ, Poulton R, Taylor DR, Greene JM, McLachlan CR, Cowan JO, Flannery EM, Herbison GP, Sears MR. Sex differences in the relation between body mass index and asthma and atopy in a birth cohort. Am J Respir Crit Care Med. 2005; 171: 440-445. 


\author{
16. Nicolacakis K, Skowronski ME, Coreno AJ, West E, Nader NZ, Smith RL, \\ McFadden ER. Observevation on the physiological interactions between obesity and \\ asthma. J Appl Physiol. 2008: 105: 1533-1541.
}
17. Viljanen A, Halttunen P, Kreus K, Viljanen BC: Spirometric studies in non-smoking healthy adults. Scand J Clin Lab Invest. 1982; 159 (Suppl): 5-20.

18. Spathopoulos D, Paraskakis E, Trypsianis G,Tsalkidis A, Arvanitidou V, Emporiadou M, Bouros D, Chatzimichael A. The Effect of Obesity on Pulmonary Lung Function of School Aged Children in Greece. Pediatr Pulmon. 2009: 44: 273-280.

19. Deane S, Thomson A. Obesity and pulmonologist. Review. Arch Dis Child. 2006; 91: $188-191$.

20. Sin DD, Sutherland ER. Obesity and the lung: 4 obesity and asthma. Thorax 2008; 63: 1018-1023.

21. Rubinstein I, Zamel N, DuBarry L, Hoffstein MD. Airflow limitation in morbidly obese, nonsmoking men. Ann Intern Med. 1990; 112: 828-832.

22. Jones RL, Nzekwu MMU. The effects of body mass index on lung volumes. Chest. 2006; 130:.827-833.

23. Sin DD, Jones RL, Man SFP. Obesity is a risk factor for dyspnea but not for airflow obstruction. Arch Intern Med. 2002; 162: 1477-1481.

24. Stenius-Aarniala B, Pousa T, Kvarnström J. Grönlund E-L, Ylikahri M, Mustajoki P. Immediate and long term effects of weight reduction in obese people with asthma: randomized controlled study. BMJ. 2000; 320: 827-832 
25. Li AM, Chan D, Wong E, Yin J, Nelson EAS, Fok TF. The effect of obesity on pulmonary function. Arch Dis Child 2003; 88: 361-363.

26. He Q, Qong T, Du L, Jiang Z, Qui H, Gao Y, Liu J, Wu J, Yu IT . Respiratory Health in overweight and obese chinese children. Pediatr Pulmonol. 2009: 44: 997-1002

27. Fung KP, Lau SP, Chow OKW, Lee J, Wong TW. Effect of overweight on lung function. Arch Dis Child. 1990; 65: 512-515.

28. Reijonen TM, Kotaniemi-Syrjanen A, Korhonen K, Korppi M. Predictors of asthma three years after hospital admission for wheezing in infancy. Pediatrics. 2000; 106: 14061412

29. Kotaniemi-Syrjänen A, Reijonen TM, Korhonen K, Korppi M. Wheezing requiring hospitalization in early childhood: predictive factors for asthma in a six-year follow-up. Pediatr Allergy Immunol. 2002; 13: 418-425.

30. Hyvärinen MK, Kotaniemi-Syrjänen A, Reijonen TM, Korhonen K, Korppi MO. Teenage asthma after severe early childhood wheezing: an 11-year prospective followup. Pediatr Pulmonol. 2005; 40: 316-323.

31. Reijonen T, Korppi M, Kuikka L, Remes K. Anti-inflammatory therapy reduces wheezing after bronchiolitis. Arch Pediatr Adolesc Med. 1996; 150: 512-517.

32. Reijonen TM, Korppi M. One-year follow-up of young children hospitalized for wheezing: the influence of early anti-inflammatory therapy and risk factors for subsequent wheezing and asthma. Pediatr Pulmonol. 1998; 26: 113-119.

John Wiley \& Sons, Inc. 
33. Kotaniemi-Syrjänen A, Vainionpaa R, Reijonen TM, Waris M, Korhonen K, Korppi

M. Rhinovirus-induced wheezing in infancy--the first sign of childhood asthma? J

Allergy Clin Immunol. 2003; 11: 66-71.

34. Korppi M, Kotaniemi-Syrjanen A, Waris M, Vainionpaa R, Reijonen TM.

Rhinovirus-associated wheezing in infancy: comparison with respiratory syncytial virus bronchiolitis. Pediatr Infect Dis J. 2004; 23: 995-999.

35. Kotaniemi-Syrjänen, Laatikainen A, Waris M, Reijonen T, Vainionpää R, Korppi M. Respiratory syncytial virus infection in children hospitalized for wheezing: Virus-specific studies from infancy to preschool years. Acta Paediatr. 2005; 94: 159-164.

36. Northwest Institute for Bio-Health Informatics. Child obesity calculator using British 1990 growth reference data. Available at: http://www.phsim.man.ac.uk/. Accessed January 18, 2007.

37. Cole TJ, Freeman JV, Preece MA. Body mass index reference curves for the UK, 1990. Arch Dis Child. 1995; 73: 25-29.

38. Freeman JV, Cole TJ, Chinn S, Jones PR, White EM, Preece MA. Cross sectional stature and weight reference curves for the UK, 1990. Arch Dis Child 1995; 73: 17-24.

39. Cole TJ, Freeman JV, Preece MA. British 1990 growth reference centiles for weight, height, body mass index and head circumference fitted by maximum penalized likelihood. Stat Med 1998; 17: 407-429

40. Cole TJ. The LMS method for constructing normalized growth standards. Eur J Clin Nutr 1990; 44: 45-60. 
41. Cole TJ, Bellizzi MC, Flegal KM, Dietz WH. Establishing a standard definition for child overweight and obesity worldwide: international survey. Brit Med J 2000; 320: $1240-1246$.

42. Koillinen H, Wanne O, Niemi V, Laakkonen E. Reference values for flow-volume spirometry and peak expiratory flow rates in healthy Finnish children. Finnish Medical Journal 1998; 5: 395-402. (in Finnish).

43. Kotaniemi-Syrjänen A, Reijonen TM, Korhonen K, Waris M, Vainionpää R, Korppi M. Wheezing due to rhinovirus infection in infancy: Bronchial hyperresponsiveness at school age. Pediatr Internat. 2008: 50;.506-510.

44. Hyvärinen MK, Kotaniemi-Syrjänen A, Reijonen T, Korhonen K, Korppi M. Lung function and bronchial hyper-responsiveness 11 years after hospitalization for chonchiolitis. Acta Paeditr. 2007; 96: 1464-1469.

45. Kautiainen S, Rimpelä A, Vikat A, Virtanen SM. Secular trends in overweight and obesity among Finnish adolescents in 1977-1999. Int J Obes Relat Metab Disord. 2002; 26: $544-52$.

46. van Veen IH, Ten Brinke A, Sterk PJ, Rabe KF, Bel EH. Airway inflammation in obese and non-obese patients with difficult-to-treat asthma. Allergy. 2008; 63: 570-574.

47. Peres-Padilla R, Rojas R, Torres V, Borja-Aburto V, Olaiz G. Obesity among Children Residing in Mexico City and its Impact on Lung Function: A Comparison with Mexican-Americans. Arch Med Res. 2006; 156-171. 
48. Lazarus R, Colditz G, Berkey C, Speizer F. Effects of body fat on ventilatory function in children and adolecents: cross-sectional findings from a random population sample of school children. Pediatr Pulmon. 1997; 24: 187-194.

49. Tantisira KG, Litonjua AA, Weiss ST, Fuhlbrigge AL (Childhood asthma management program research group). Association of body mass with pulmonary function in the childhood asthma management program (CAMP). Thorax. 2003; 58: 1036-1041.

50. Bua J, Prescott E, Schack-Nielsen L, Petersen L, Godtfredsen NS, Sørensen TI, Osler M. Weight history from birth through childhood and youth in relation to adult lung function, in Danish juvenile obese and non-obese men. Int J Obes (Lond). 2005; 29: 1055-1062. 
Table 1. Flow-volume spirometry (FVS, $\%$ of predicted, mean, SD) in 74 study subjects at 7.2 years of age, in relation to current overweight or obesity (at 7.2 years of age).

\begin{tabular}{|c|c|c|c|c|c|c|c|c|}
\hline \multirow[t]{2}{*}{$\begin{array}{c}\text { Parameters } \\
\text { in FVS }\end{array}$} & \multicolumn{2}{|c|}{$\begin{array}{c}\text { Current } \\
\text { overweight }^{\mathrm{a}}\end{array}$} & \multirow[b]{2}{*}{$\begin{array}{l}\text { Univariate } \\
\text { p }\end{array}$} & \multirow[b]{2}{*}{$\begin{array}{l}\text { Multivariate } \\
p^{d}\end{array}$} & \multicolumn{2}{|c|}{ Current obesity } & \multirow[b]{2}{*}{$\begin{array}{l}\text { Univariate } \\
\text { p }^{c}\end{array}$} & \multirow[b]{2}{*}{$\begin{array}{l}\text { Multivariate } \\
\qquad \mathbf{p}^{\mathbf{d}}\end{array}$} \\
\hline & $\begin{array}{c}\text { Yes } \\
(\mathrm{N}=16) \\
\text { Mean, } \\
(\mathrm{SD})\end{array}$ & $\begin{array}{c}\text { No } \\
(\mathrm{N}=58) \\
\text { Mean, } \\
(\mathrm{SD})\end{array}$ & & & $\begin{array}{c}\text { Yes } \\
(\mathrm{N}=7) \\
\text { Mean, } \\
(\mathrm{SD})\end{array}$ & $\begin{array}{c}\text { No } \\
(\mathrm{N}=72) \\
\text { Mean, } \\
\text { (SD) }\end{array}$ & & \\
\hline FVC & $\begin{array}{l}108.71 \\
(19.75)\end{array}$ & $\begin{array}{l}102.06 \\
(16.48)\end{array}$ & 0.252 & 0.219 & $\begin{array}{l}106.73 \\
(8.78)\end{array}$ & $\begin{array}{l}103.27 \\
(18.00)\end{array}$ & 0.448 & 0.467 \\
\hline FEV $_{1}$ & $\begin{array}{l}100.16 \\
(14.16)\end{array}$ & $\begin{array}{c}99.95 \\
(13.94)\end{array}$ & 0.977 & 0.890 & $\begin{array}{l}96.58 \\
(4.78)\end{array}$ & $\begin{array}{l}100.33 \\
(14.46)\end{array}$ & 0.523 & 0.574 \\
\hline $\mathrm{FEV}_{1} / \mathrm{FVC}$ & $\begin{array}{l}92.63 \\
(8.95)\end{array}$ & $\begin{array}{l}98.47 \\
(8.93)\end{array}$ & 0.017 & 0.025 & $\begin{array}{l}90.81 \\
(7.62)\end{array}$ & $\begin{array}{l}97.76 \\
(9.17)\end{array}$ & 0.076 & 0.034 \\
\hline $\mathbf{M E F}_{50}$ & $\begin{array}{c}84.00 \\
(17.73)\end{array}$ & $\begin{array}{c}85.10 \\
(20.39)\end{array}$ & 0.700 & 0.814 & $\begin{array}{l}81.30 \\
(19.03)\end{array}$ & $\begin{array}{l}85.19 \\
(19.87)\end{array}$ & 0.546 & 0.615 \\
\hline $\mathbf{M E F}_{25}$ & $\begin{array}{c}66.00 \\
(19.85)\end{array}$ & $\begin{array}{c}71.27 \\
(22.76)\end{array}$ & 0.394 & 0.454 & $\begin{array}{l}62.77 \\
(17.30)\end{array}$ & $\begin{array}{l}70.78 \\
(22.50)\end{array}$ & 0.398 & 0.305 \\
\hline
\end{tabular}

${ }^{\text {a }}$ Overweight BMI-SDS > 1.3 (obese children included); obesity BMI-SDS > 2,0

${ }^{\mathrm{b}} \mathrm{FVC}$ (forced vital capacity), $\mathrm{FEV}_{1}$ (forced expiratory volume in one second), FEV1/FCV, $\mathrm{MEF}_{50}$ (maximal expiratory flow at $50 \%$ of $\mathrm{FVC}$ ) and $\mathrm{MEF}_{25}$ (maximal expiratory flow at $25 \%$ of $\mathrm{FVC}$ ), expressed as \% of predicted.

${ }^{\mathrm{c}}$ Mann-Whitney U -test

${ }^{\mathrm{d}}$ Analysis of variance, adjusted for RSV etiology of early wheezing and current anti-inflammatory asthma medication (during the preceding 12 months). 
Table 2. Flow-volume spirometry (FVS, \% of predicted, mean, SD) in 80 study subjects at 12.3 years of age, in relation to previous (at 7.2 years of age) and current (at 12.3 years of age) overweight.

\begin{tabular}{|c|c|c|c|c|c|c|c|c|}
\hline \multirow[t]{2}{*}{$\begin{array}{c}\text { Parameters } \\
\text { in FVS }\end{array}$} & \multicolumn{2}{|c|}{$\begin{array}{c}\text { Previous } \\
\text { overweight }^{\mathrm{a}}\end{array}$} & \multirow[b]{2}{*}{$\begin{array}{l}\text { Univariate } \\
\mathbf{p}^{\mathbf{c}}\end{array}$} & \multirow[b]{2}{*}{$\begin{array}{l}\text { Multivariate } \\
\mathbf{p}^{d}\end{array}$} & \multicolumn{2}{|c|}{$\begin{array}{c}\text { Current } \\
\text { overweight }^{\mathrm{a}}\end{array}$} & \multirow[b]{2}{*}{$\begin{array}{l}\text { Univariate } \\
\mathbf{p}^{\mathrm{c}}\end{array}$} & \multirow[b]{2}{*}{$\begin{array}{l}\text { Multivariate } \\
\mathbf{p}^{\mathrm{d}}\end{array}$} \\
\hline & $\begin{array}{c}\text { Yes } \\
(\mathrm{N}=16) \\
\text { Mean, } \\
(\mathrm{SD})\end{array}$ & $\begin{array}{c}\text { No } \\
(\mathrm{N}=58) \\
\text { Mean, } \\
(\mathrm{SD})\end{array}$ & & & $\begin{array}{c}\text { Yes } \\
(\mathrm{N}=27) \\
\text { Mean, } \\
(\mathrm{SD})\end{array}$ & $\begin{array}{c}\text { No } \\
(\mathrm{N}=53) \\
\text { Mean, } \\
\text { (SD) }\end{array}$ & & \\
\hline FVC & $\begin{array}{l}101.03 \\
(8.40)\end{array}$ & $\begin{array}{c}97.21 \\
(13.20)\end{array}$ & 0.131 & 0.306 & $\begin{array}{l}100.56 \\
(11.50)\end{array}$ & $\begin{array}{c}96.38 \\
(12.68)\end{array}$ & 0.162 & 0.164 \\
\hline FEV $_{1}$ & $\begin{array}{c}90.21 \\
(12.96)\end{array}$ & $\begin{array}{l}93.03 \\
(12.96)\end{array}$ & 0.684 & 0.420 & $\begin{array}{l}90.68 \\
(13.60)\end{array}$ & $\begin{array}{l}93.02 \\
(21.50)\end{array}$ & 0.439 & 0.500 \\
\hline $\mathrm{FEV}_{\mathbf{1}} / \mathrm{FVC}$ & $\begin{array}{c}89.15 \\
(10.06)\end{array}$ & $\begin{array}{l}96.01 \\
(7.63)\end{array}$ & 0.013 & 0.003 & $\begin{array}{l}90.09 \\
(8.81)\end{array}$ & $\begin{array}{l}96.81 \\
(7.36)\end{array}$ & 0.001 & 0.001 \\
\hline $\mathbf{M E F}_{50}$ & $\begin{array}{l}74.88 \\
(20.68)\end{array}$ & $\begin{array}{c}83.91 \\
(18.82)\end{array}$ & 0.121 & 0.095 & $\begin{array}{l}75.63 \\
(20.47)\end{array}$ & $\begin{array}{c}84.39 \\
(17.70)\end{array}$ & 0.037 & 0.076 \\
\hline $\mathbf{M E F}_{25}$ & $\begin{array}{c}64.49 \\
(23.75)\end{array}$ & $\begin{array}{l}73.18 \\
(19.25)\end{array}$ & 0.138 & 0.139 & $\begin{array}{l}62.96 \\
(19.58)\end{array}$ & $\begin{array}{l}76.13 \\
(19.85)\end{array}$ & 0.006 & 0.009 \\
\hline
\end{tabular}

${ }^{\mathrm{a}}$ BMI-SDS $>1.3$

${ }^{\mathrm{b}} \mathrm{FVC}$ (forced vital capacity), $\mathrm{FEV}_{1}$ (forced expiratory volume in one second), $\mathrm{FEV}_{1} / \mathrm{FCV}, \mathrm{MEF}_{50}$ (maximal expiratory flow at $50 \%$ of $\mathrm{FVC}$ ) and $\mathrm{MEF}_{25}$ (maximal expiratory flow at $25 \%$ of $\mathrm{FVC}$ ), expressed as $\%$ of predicted.

${ }^{\mathrm{c}}$ Mann-Whitney U -test

${ }^{\mathrm{d}}$ Analysis of variance, adjusted for RSV etiology of early wheezing and current anti-inflammatory asthma medication (during the preceding 12 months). 
Table 3. Flow-volume spirometry (FVS, \% of predicted, mean, SD) in 80 study subjects at 12.3 years of age, in relation to previous (at 7.2 years of age) and current (at 12.3 years of age) obesity.

\begin{tabular}{|c|c|c|c|c|c|c|c|c|}
\hline \multirow[b]{2}{*}{$\begin{array}{c}\text { Parameters } \\
\text { in } \mathbf{F V S}^{\mathbf{b}}\end{array}$} & \multicolumn{2}{|c|}{$\begin{array}{c}\text { Previous } \\
\text { obesity }^{\text {a }}\end{array}$} & \multirow[b]{2}{*}{$\begin{array}{l}\text { Univariate } \\
\mathbf{p}^{\mathbf{c}}\end{array}$} & \multirow[b]{2}{*}{$\begin{array}{c}\text { Multivariate } \\
\mathbf{p}^{d}\end{array}$} & \multicolumn{2}{|c|}{$\begin{array}{l}\text { Current } \\
\text { obesity }^{\text {a }}\end{array}$} & \multirow[b]{2}{*}{$\begin{array}{c}\text { Univariate } \\
\mathbf{p}^{\mathbf{c}}\end{array}$} & \multirow[b]{2}{*}{$\begin{array}{c}\text { Multivariate } \\
\mathbf{p}^{\mathbf{d}}\end{array}$} \\
\hline & $\begin{array}{c}\text { Yes } \\
(\mathrm{N}=6) \\
\text { Mean, } \\
(\mathrm{SD})\end{array}$ & $\begin{array}{c}\text { No } \\
(\mathrm{N}=68) \\
\text { Mean, } \\
(\mathrm{SD}) \\
\end{array}$ & & & $\begin{array}{c}\text { Yes } \\
(\mathrm{N}=16) \\
\text { Mean, } \\
(\mathrm{SD})\end{array}$ & $\begin{array}{c}\text { No } \\
(\mathrm{N}=64) \\
\text { Mean, } \\
(\mathrm{SD})\end{array}$ & & \\
\hline FVC & $\begin{array}{l}99.05 \\
(9.47)\end{array}$ & $\begin{array}{c}97.95 \\
(12.65)\end{array}$ & 0.797 & 0.769 & $\begin{array}{l}98.39 \\
(9.12)\end{array}$ & $\begin{array}{c}97.64 \\
(13.12)\end{array}$ & 0.674 & 0.837 \\
\hline FEV $_{1}$ & $\begin{array}{c}87.28 \\
(13.30)\end{array}$ & $\begin{array}{l}92.87 \\
(12.89)\end{array}$ & 0.434 & 0.318 & $\begin{array}{c}87.44 \\
(12.69)\end{array}$ & $\begin{array}{c}93.43 \\
(12.86)\end{array}$ & 0.136 & 0.116 \\
\hline $\mathrm{FEV}_{1} / \mathrm{FVC}$ & $\begin{array}{l}87.76 \\
(6.99)\end{array}$ & $\begin{array}{l}95.12 \\
(8.57)\end{array}$ & 0.022 & 0.026 & $\begin{array}{l}88.85 \\
(9.78)\end{array}$ & $\begin{array}{l}95.97 \\
(7.51)\end{array}$ & 0.010 & 0.002 \\
\hline $\mathbf{M E F}_{50}$ & $\begin{array}{c}70.46 \\
(15.72)\end{array}$ & $\begin{array}{c}82.97 \\
(19.52)\end{array}$ & 0.132 & 0.107 & $\begin{array}{c}71.68 \\
(18.81)\end{array}$ & $\begin{array}{c}83.87 \\
(18.41)\end{array}$ & 0.025 & 0.028 \\
\hline $\mathbf{M E F}_{25}$ & $\begin{array}{c}60.03 \\
(10.59)\end{array}$ & $\begin{array}{c}72.34 \\
(20.84)\end{array}$ & 0.113 & 0.130 & $\begin{array}{c}61.02 \\
(21.40)\end{array}$ & $\begin{array}{c}74.35 \\
(19.68)\end{array}$ & 0.021 & 0.024 \\
\hline
\end{tabular}

${ }^{\mathrm{a}} \mathrm{BMI}-\mathrm{SDS}>2$

${ }^{\mathrm{b}} \mathrm{FVC}$ (forced vital capacity), $\mathrm{FEV}_{1}$ (forced expiratory volume in one second), $\mathrm{FEV}_{1} / \mathrm{FCV}, \mathrm{MEF}_{50}$ (maximal expiratory flow at $50 \%$ of $\mathrm{FVC}$ ) and $\mathrm{MEF}_{25}$ (maximal expiratory flow at $25 \%$ of FVC), expressed as \% of predicted.

${ }^{c}$ Mann-Whitney U -test

${ }^{\mathrm{d}}$ Analysis of variance, adjusted for RSV etiology of early wheezing and current anti-inflammatory asthma medication (during the preceding 12 months). 
Table 4. Logistic regression: abnormal lung function in flow-volume spirometry (FVS) at 7.2 years of age, in relation to previous (at 4.0 years of age) and current (at 7.2 years of age) overweight.

\begin{tabular}{|c|c|c|c|c|c|c|}
\hline \multirow{2}{*}{ Abnormal FVS ${ }^{b}$} & \multicolumn{2}{|c|}{$\begin{array}{c}\text { Previous } \\
\text { overweight }^{\text {a }}\end{array}$} & \multirow{2}{*}{$\begin{array}{c}\mathrm{aOR}^{\mathrm{c}} \\
(95 \% \mathrm{CI})\end{array}$} & \multicolumn{2}{|c|}{$\begin{array}{c}\text { Current } \\
\text { overweight }^{\mathrm{a}}\end{array}$} & \multirow{2}{*}{$\begin{array}{c}\mathbf{a O R}^{\mathrm{c}} \\
(95 \% \mathrm{CI})\end{array}$} \\
\hline & $\begin{array}{c}\text { Yes } \\
(\mathrm{N}=5)\end{array}$ & $\begin{array}{c}\mathrm{No} \\
(\mathrm{N}=69)\end{array}$ & & $\begin{array}{c}\text { Yes } \\
(\mathrm{N}=17)\end{array}$ & $\begin{array}{c}\mathrm{No} \\
(\mathrm{N}=57)\end{array}$ & \\
\hline $\mathrm{FEV}_{1}<\mathbf{8 0 \%}$ & 0 & 4 & - & 1 & 3 & $\begin{array}{c}1.01 \\
(0.10-10.58)\end{array}$ \\
\hline $\mathrm{FEV}_{1} / \mathrm{FVC}<88 \%$ & 3 & 10 & $\begin{array}{c}15.46 \\
(1.65-145.26)\end{array}$ & 6 & 7 & $\begin{array}{c}3.71 \\
(1.01-13.60)\end{array}$ \\
\hline $\mathrm{MEF}_{50}<62 \%$ & 2 & 11 & $\begin{array}{c}6.46 \\
(0.772-33.95)\end{array}$ & 3 & 11 & $\begin{array}{c}0.89 \\
(0.21-3.80)\end{array}$ \\
\hline $\mathrm{MEF}_{25}<48 \%$ & 2 & 12 & $\begin{array}{c}4.74 \\
(0.61-36.76)\end{array}$ & 3 & 11 & $\begin{array}{c}0.89 \\
(0.22-3.70)\end{array}$ \\
\hline $\begin{array}{c}\text { At least one } \\
\text { abnormal parameter }\end{array}$ & 3 & 16 & $\begin{array}{c}6.63 \\
(0.89-49.46)\end{array}$ & 6 & 14 & $\begin{array}{c}1.63 \\
(0.51-5.22)\end{array}$ \\
\hline
\end{tabular}

${ }^{a}$ BMI-SDS $>1.3$

${ }^{\mathrm{b}} \mathrm{FVC}$ (forced vital capacity), $\mathrm{FEV}_{1}$ (forced expiratory volume in one second), $\mathrm{FEV}_{1} / \mathrm{FCV}, \mathrm{MEF}_{50}$ (maximal expiratory flow at $50 \%$ of $\mathrm{FVC}$ ) and $\mathrm{MEF}_{25}$ (maximal expiratory flow at $25 \%$ of $\mathrm{FVC}$ ), expressed as $\%$ of predicted.

${ }^{\mathrm{c}}$ Odds ratio (95\% confidence interval) adjusted for RSV etiology of early wheezing and current antiinflammatory asthma medication (during the preceding 12 months) 
Table 5. Logistic regression: abnormal lung function in flow-volume spirometry (FVS) at 12.3 years of age, in relation to previous (at 7.2 years of age) and current (at 12.3 years of age) overweight.

\begin{tabular}{|c|c|c|c|c|c|c|}
\hline \multirow{2}{*}{ Abnormal FVS } & \multicolumn{2}{|c|}{$\begin{array}{c}\text { Previous } \\
\text { overweight }^{\text {a }}\end{array}$} & \multirow{2}{*}{$\begin{array}{c}\mathrm{aOR}^{\mathrm{c}} \\
(95 \% \mathrm{CI})\end{array}$} & \multicolumn{2}{|c|}{$\begin{array}{c}\text { Current } \\
\text { overweight }^{\mathrm{a}}\end{array}$} & \multirow{2}{*}{$\begin{array}{c}\mathrm{aOR}^{\mathrm{c}} \\
(95 \% \mathrm{CI})\end{array}$} \\
\hline & $\begin{array}{c}\text { Yes } \\
(\mathrm{N}=16)\end{array}$ & $\begin{array}{c}\text { No } \\
(\mathrm{N}=58)\end{array}$ & & $\begin{array}{c}\text { Yes } \\
(\mathrm{N}=24)\end{array}$ & $\begin{array}{c}\text { No } \\
(\mathrm{N}=50)\end{array}$ & \\
\hline $\operatorname{FEV}_{1}<80 \%$ & 2 & 10 & $\begin{array}{c}0.70 \\
(0.13-3.60)\end{array}$ & 5 & 9 & $\begin{array}{c}1.00 \\
(0.29-3.46)\end{array}$ \\
\hline $\mathrm{FEV}_{1} / \mathrm{FVC}<88 \%$ & 6 & 6 & $\begin{array}{c}5.64 \\
(1.43-22.20)\end{array}$ & 8 & 5 & $\begin{array}{c}4.02 \\
(1.14-14.22)\end{array}$ \\
\hline $\mathrm{MEF}_{50}<62 \%$ & 3 & 9 & $\begin{array}{c}1.29 \\
(0.30-5.54)\end{array}$ & 7 & 6 & $\begin{array}{c}2.64 \\
(0.78-8.97)\end{array}$ \\
\hline $\mathrm{MEF}_{25}<48 \%$ & 4 & 6 & $\begin{array}{c}3.51 \\
(0.76-16.13)\end{array}$ & 6 & 5 & $\begin{array}{c}2.47 \\
(0.65-9.38)\end{array}$ \\
\hline $\begin{array}{l}\text { At least one } \\
\text { abnormal } \\
\text { parameter }\end{array}$ & 6 & 17 & $\begin{array}{c}1.45 \\
(0.45-4.67)\end{array}$ & 11 & 15 & $\begin{array}{c}1.70 \\
(0.63-4.55)\end{array}$ \\
\hline
\end{tabular}

${ }^{\mathrm{a}} \mathrm{BMI}-\mathrm{SDS}>1.3$

${ }^{\mathrm{b}} \mathrm{FVC}$ (forced vital capacity), $\mathrm{FEV}_{1}$ (forced expiratory volume in one second), $\mathrm{FEV}_{1} / \mathrm{FCV}, \mathrm{MEF}_{50}$ (maximal expiratory flow at $50 \%$ of $\mathrm{FVC}$ ) and $\mathrm{MEF}_{25}$ (maximal expiratory flow at $25 \%$ of $\mathrm{FVC}$ ), expressed as \% of predicted.

${ }^{c}$ Odds ratio (95\% confidence interval) adjusted for RSV etiology of early wheezing and current antiinflammatory asthma medication (during the preceding 12 months) 
Table 1. Flow-volume spirometry (FVS, \% of predicted, mean, SD) in 74 study subjects at 7.2 years of age, in relation to current overweight or obesity (at 7.2 years of age).

\begin{tabular}{|c|c|c|c|c|c|c|c|c|}
\hline \multirow[t]{2}{*}{$\begin{array}{c}\text { Parameters } \\
\text { in FVS }\end{array}$} & \multicolumn{2}{|c|}{$\begin{array}{c}\text { Current } \\
\text { overweight }^{\mathrm{a}}\end{array}$} & \multirow[b]{2}{*}{$\begin{array}{l}\text { Univariate } \\
\text { p }\end{array}$} & \multirow[b]{2}{*}{$\begin{array}{l}\text { Multivariate } \\
p^{d}\end{array}$} & \multicolumn{4}{|c|}{ Current obesity $^{\mathrm{a}}$} \\
\hline & $\begin{array}{c}\text { Yes } \\
(\mathrm{N}=16) \\
\text { Mean, } \\
(\mathrm{SD})\end{array}$ & $\begin{array}{c}\text { No } \\
(\mathrm{N}=58) \\
\text { Mean, } \\
(\mathrm{SD})\end{array}$ & & & $\begin{array}{l}\text { Yes } \\
(\mathrm{N}=7) \\
\text { Mean, } \\
(\mathrm{SD})\end{array}$ & $\begin{array}{c}\text { No } \\
(\mathrm{N}=72) \\
\text { Mean, } \\
\text { (SD) }\end{array}$ & $\begin{array}{c}\text { Univariate } \\
\mathbf{p}^{c}\end{array}$ & $\begin{array}{c}\text { Multivariate } \\
\mathbf{p}^{\mathbf{d}}\end{array}$ \\
\hline FVC & $\begin{array}{l}108.71 \\
(19.75)\end{array}$ & $\begin{array}{c}102.06 \\
(16.48)\end{array}$ & 0.252 & 0.219 & $\begin{array}{l}106.73 \\
(8.78)\end{array}$ & $\begin{array}{l}103.27 \\
(18.00)\end{array}$ & 0.448 & 0.467 \\
\hline FEV $_{1}$ & $\begin{array}{l}100.16 \\
(14.16)\end{array}$ & $\begin{array}{c}99.95 \\
(13.94)\end{array}$ & 0.977 & 0.890 & $\begin{array}{l}96.58 \\
(4.78)\end{array}$ & $\begin{array}{l}100.33 \\
(14.46)\end{array}$ & 0.523 & 0.574 \\
\hline FEV $_{1} /$ FVC & $\begin{array}{l}92.63 \\
(8.95)\end{array}$ & $\begin{array}{l}98.47 \\
(8.93)\end{array}$ & 0.017 & 0.025 & $\begin{array}{l}90.81 \\
(7.62)\end{array}$ & $\begin{array}{l}97.76 \\
(9.17)\end{array}$ & 0.076 & 0.034 \\
\hline $\mathbf{M E F}_{50}$ & $\begin{array}{c}84.00 \\
(17.73)\end{array}$ & $\begin{array}{c}85.10 \\
(20.39)\end{array}$ & 0.700 & 0.814 & $\begin{array}{l}81.30 \\
(19.03)\end{array}$ & $\begin{array}{l}85.19 \\
(19.87)\end{array}$ & 0.546 & 0.615 \\
\hline $\mathbf{M E F}_{25}$ & $\begin{array}{c}66.00 \\
(19.85)\end{array}$ & $\begin{array}{c}71.27 \\
(22.76)\end{array}$ & 0.394 & 0.454 & $\begin{array}{l}62.77 \\
(17.30)\end{array}$ & $\begin{array}{l}70.78 \\
(22.50)\end{array}$ & 0.398 & 0.305 \\
\hline
\end{tabular}

${ }^{\text {a }}$ Overweight BMI-SDS >1.3 (obese children included); obesity BMI-SDS > 2,0

${ }^{\mathrm{b}} \mathrm{FVC}$ (forced vital capacity), $\mathrm{FEV}_{1}$ (forced expiratory volume in one second), FEV1/FCV, $\mathrm{MEF}_{50}$ (maximal expiratory flow at $50 \%$ of FVC) and $\mathrm{MEF}_{25}$ (maximal expiratory flow at $25 \%$ of FVC), expressed as $\%$ of predicted.

${ }^{\mathrm{c}}$ Mann-Whitney U -test

${ }^{\mathrm{d}}$ Analysis of variance, adjusted for RSV etiology of early wheezing and current anti-inflammatory asthma medication (during the preceding 12 months). 
Table 2. Flow-volume spirometry (FVS, \% of predicted, mean, SD) in 80 study subjects at 12.3 years of age, in relation to previous (at 7.2 years of age) and current (at 12.3 years of age) overweight.

6

\section{Parameters} in FVS ${ }^{\mathbf{b}}$

${ }^{\mathrm{a}}$ BMI-SDS $>1.3$

${ }^{\mathrm{b}} \mathrm{FVC}$ (forced vital capacity), $\mathrm{FEV}_{1}$ (forced expiratory volume in one second), $\mathrm{FEV}_{1} / \mathrm{FCV}, \mathrm{MEF}_{50}$ (maximal expiratory flow at $50 \%$ of $\mathrm{FVC}$ ) and $\mathrm{MEF}_{25}$ (maximal expiratory flow at $25 \%$ of $\mathrm{FVC}$ ), expressed as \% of predicted.

${ }^{\mathrm{c}}$ Mann-Whitney U -test

${ }^{\mathrm{d}}$ Analysis of variance, adjusted for RSV etiology of early wheezing and current anti-inflammatory asthma medication (during the preceding 12 months). 
Table 3. Flow-volume spirometry (FVS, \% of predicted, mean, SD) in 80 study subjects at 12.3 years of age, in relation to previous (at 7.2 years of age) and current (at 12.3 years of age) obesity.

\begin{tabular}{|c|c|c|c|c|c|c|c|c|}
\hline \multirow[b]{2}{*}{$\begin{array}{c}\text { Parameters } \\
\text { in } \mathbf{F V S}^{\mathbf{b}}\end{array}$} & \multicolumn{2}{|c|}{$\begin{array}{c}\text { Previous } \\
\text { obesity }^{\text {a }}\end{array}$} & \multirow[b]{2}{*}{$\begin{array}{l}\text { Univariate } \\
\mathbf{p}^{\mathbf{c}}\end{array}$} & \multirow[b]{2}{*}{$\begin{array}{c}\text { Multivariate } \\
\mathbf{p}^{d}\end{array}$} & \multicolumn{2}{|c|}{$\begin{array}{l}\text { Current } \\
\text { obesity }^{\text {a }}\end{array}$} & \multirow[b]{2}{*}{$\begin{array}{c}\text { Univariate } \\
\mathbf{p}^{\mathbf{c}}\end{array}$} & \multirow[b]{2}{*}{$\begin{array}{c}\text { Multivariate } \\
\mathbf{p}^{\mathbf{d}}\end{array}$} \\
\hline & $\begin{array}{c}\text { Yes } \\
(\mathrm{N}=6) \\
\text { Mean, } \\
(\mathrm{SD})\end{array}$ & $\begin{array}{c}\text { No } \\
(\mathrm{N}=68) \\
\text { Mean, } \\
(\mathrm{SD}) \\
\end{array}$ & & & $\begin{array}{c}\text { Yes } \\
(\mathrm{N}=16) \\
\text { Mean, } \\
(\mathrm{SD})\end{array}$ & $\begin{array}{c}\text { No } \\
(\mathrm{N}=64) \\
\text { Mean, } \\
(\mathrm{SD})\end{array}$ & & \\
\hline FVC & $\begin{array}{l}99.05 \\
(9.47)\end{array}$ & $\begin{array}{c}97.95 \\
(12.65)\end{array}$ & 0.797 & 0.769 & $\begin{array}{l}98.39 \\
(9.12)\end{array}$ & $\begin{array}{c}97.64 \\
(13.12)\end{array}$ & 0.674 & 0.837 \\
\hline FEV $_{1}$ & $\begin{array}{c}87.28 \\
(13.30)\end{array}$ & $\begin{array}{l}92.87 \\
(12.89)\end{array}$ & 0.434 & 0.318 & $\begin{array}{c}87.44 \\
(12.69)\end{array}$ & $\begin{array}{c}93.43 \\
(12.86)\end{array}$ & 0.136 & 0.116 \\
\hline $\mathrm{FEV}_{1} / \mathrm{FVC}$ & $\begin{array}{l}87.76 \\
(6.99)\end{array}$ & $\begin{array}{l}95.12 \\
(8.57)\end{array}$ & 0.022 & 0.026 & $\begin{array}{l}88.85 \\
(9.78)\end{array}$ & $\begin{array}{l}95.97 \\
(7.51)\end{array}$ & 0.010 & 0.002 \\
\hline $\mathbf{M E F}_{50}$ & $\begin{array}{c}70.46 \\
(15.72)\end{array}$ & $\begin{array}{c}82.97 \\
(19.52)\end{array}$ & 0.132 & 0.107 & $\begin{array}{c}71.68 \\
(18.81)\end{array}$ & $\begin{array}{c}83.87 \\
(18.41)\end{array}$ & 0.025 & 0.028 \\
\hline $\mathbf{M E F}_{25}$ & $\begin{array}{c}60.03 \\
(10.59)\end{array}$ & $\begin{array}{c}72.34 \\
(20.84)\end{array}$ & 0.113 & 0.130 & $\begin{array}{c}61.02 \\
(21.40)\end{array}$ & $\begin{array}{c}74.35 \\
(19.68)\end{array}$ & 0.021 & 0.024 \\
\hline
\end{tabular}

${ }^{\mathrm{a}} \mathrm{BMI}-\mathrm{SDS}>2$

${ }^{\mathrm{b}} \mathrm{FVC}$ (forced vital capacity), $\mathrm{FEV}_{1}$ (forced expiratory volume in one second), $\mathrm{FEV}_{1} / \mathrm{FCV}, \mathrm{MEF}_{50}$ (maximal expiratory flow at $50 \%$ of $\mathrm{FVC}$ ) and $\mathrm{MEF}_{25}$ (maximal expiratory flow at $25 \%$ of FVC), expressed as $\%$ of predicted.

${ }^{\mathrm{c}}$ Mann-Whitney U -test

${ }^{\mathrm{d}}$ Analysis of variance, adjusted for RSV etiology of early wheezing and current anti-inflammatory asthma medication (during the preceding 12 months). 
Table 4. Logistic regression: abnormal lung function in flow-volume spirometry (FVS) at 7.2 years of age, in relation to previous (at 4.0 years of age) and current (at 7.2 years of age) overweight.

\begin{tabular}{|c|c|c|c|c|c|c|}
\hline \multirow{2}{*}{ Abnormal FVS } & \multicolumn{2}{|c|}{$\begin{array}{c}\text { Previous } \\
\text { overweight }^{\mathrm{a}}\end{array}$} & \multirow{2}{*}{$\begin{array}{c}\mathbf{a O R}^{\mathrm{c}} \\
(95 \% \mathrm{CI})\end{array}$} & \multicolumn{2}{|c|}{$\begin{array}{c}\text { Current } \\
\text { overweight }^{\mathrm{a}}\end{array}$} & \multirow{2}{*}{$\begin{array}{c}\mathbf{a O R}^{\mathrm{c}} \\
(95 \% \mathrm{CI})\end{array}$} \\
\hline & $\begin{array}{c}\text { Yes } \\
(\mathrm{N}=5)\end{array}$ & $\begin{array}{c}\text { No } \\
(\mathrm{N}=69)\end{array}$ & & $\begin{array}{c}\text { Yes } \\
(\mathrm{N}=17) \\
\end{array}$ & $\begin{array}{c}\text { No } \\
(\mathrm{N}=57) \\
\end{array}$ & \\
\hline FEV $_{1}<80 \%$ & 0 & 4 & - & 1 & 3 & $\begin{array}{c}1.01 \\
(0.10-10.58)\end{array}$ \\
\hline $\mathrm{FEV}_{1} / \mathrm{FVC}<\mathbf{8 8 \%}$ & 3 & 10 & $\begin{array}{c}15.46 \\
(1.65-145.26)\end{array}$ & 6 & 7 & $\begin{array}{c}3.71 \\
(1.01-13.60)\end{array}$ \\
\hline $\mathrm{MEF}_{50}<62 \%$ & 2 & 11 & $\begin{array}{c}6.46 \\
(0.772-33.95)\end{array}$ & 3 & 11 & $\begin{array}{c}0.89 \\
(0.21-3.80)\end{array}$ \\
\hline $\mathrm{MEF}_{25}<48 \%$ & 2 & 12 & $\begin{array}{c}4.74 \\
(0.61-36.76)\end{array}$ & 3 & 11 & $\begin{array}{c}0.89 \\
(0.22-3.70)\end{array}$ \\
\hline $\begin{array}{c}\text { At least one } \\
\text { abnormal parameter }\end{array}$ & 3 & 16 & $\begin{array}{c}6.63 \\
(0.89-49.46)\end{array}$ & 6 & 14 & $\begin{array}{c}1.63 \\
(0.51-5.22)\end{array}$ \\
\hline
\end{tabular}

${ }^{\mathrm{a}} \mathrm{BMI}-\mathrm{SDS}>1.3$

${ }^{\mathrm{b}} \mathrm{FVC}$ (forced vital capacity), $\mathrm{FEV}_{1}$ (forced expiratory volume in one second), $\mathrm{FEV}_{1} / \mathrm{FCV}, \mathrm{MEF}_{50}$ (maximal expiratory flow at $50 \%$ of FVC) and $\mathrm{MEF}_{25}$ (maximal expiratory flow at $25 \%$ of FVC), expressed as $\%$ of predicted.

${ }^{c}$ Odds ratio (95\% confidence interval) adjusted for RSV etiology of early wheezing and current antiinflammatory asthma medication (during the preceding 12 months) 
Table 5. Logistic regression: abnormal lung function in flow-volume spirometry (FVS) at 12.3 years of age, in relation to previous (at 7.2 years of age) and current (at 12.3 years of age) overweight.

\begin{tabular}{|c|c|c|c|c|c|c|}
\hline \multirow{2}{*}{ Abnormal FVS } & \multicolumn{2}{|c|}{$\begin{array}{c}\text { Previous } \\
\text { overweight }^{\text {a }}\end{array}$} & \multirow{2}{*}{$\begin{array}{c}\mathrm{aOR}^{\mathrm{c}} \\
(95 \% \mathrm{CI})\end{array}$} & \multicolumn{2}{|c|}{$\begin{array}{c}\text { Current } \\
\text { overweight }^{\mathrm{a}}\end{array}$} & \multirow{2}{*}{$\begin{array}{c}\mathrm{aOR}^{\mathrm{c}} \\
(95 \% \mathrm{CI})\end{array}$} \\
\hline & $\begin{array}{c}\text { Yes } \\
(\mathrm{N}=16)\end{array}$ & $\begin{array}{c}\text { No } \\
(\mathrm{N}=58)\end{array}$ & & $\begin{array}{c}\text { Yes } \\
(\mathrm{N}=24)\end{array}$ & $\begin{array}{c}\text { No } \\
(\mathrm{N}=50)\end{array}$ & \\
\hline $\operatorname{FEV}_{1}<80 \%$ & 2 & 10 & $\begin{array}{c}0.70 \\
(0.13-3.60)\end{array}$ & 5 & 9 & $\begin{array}{c}1.00 \\
(0.29-3.46)\end{array}$ \\
\hline $\mathrm{FEV}_{1} / \mathrm{FVC}<88 \%$ & 6 & 6 & $\begin{array}{c}5.64 \\
(1.43-22.20)\end{array}$ & 8 & 5 & $\begin{array}{c}4.02 \\
(1.14-14.22)\end{array}$ \\
\hline $\mathrm{MEF}_{50}<62 \%$ & 3 & 9 & $\begin{array}{c}1.29 \\
(0.30-5.54)\end{array}$ & 7 & 6 & $\begin{array}{c}2.64 \\
(0.78-8.97)\end{array}$ \\
\hline $\mathrm{MEF}_{25}<48 \%$ & 4 & 6 & $\begin{array}{c}3.51 \\
(0.76-16.13)\end{array}$ & 6 & 5 & $\begin{array}{c}2.47 \\
(0.65-9.38)\end{array}$ \\
\hline $\begin{array}{l}\text { At least one } \\
\text { abnormal } \\
\text { parameter }\end{array}$ & 6 & 17 & $\begin{array}{c}1.45 \\
(0.45-4.67)\end{array}$ & 11 & 15 & $\begin{array}{c}1.70 \\
(0.63-4.55)\end{array}$ \\
\hline
\end{tabular}

${ }^{\mathrm{a}} \mathrm{BMI}-\mathrm{SDS}>1.3$

${ }^{\mathrm{b}} \mathrm{FVC}$ (forced vital capacity), $\mathrm{FEV}_{1}$ (forced expiratory volume in one second), $\mathrm{FEV}_{1} / \mathrm{FCV}, \mathrm{MEF}_{50}$ (maximal expiratory flow at $50 \%$ of $\mathrm{FVC}$ ) and $\mathrm{MEF}_{25}$ (maximal expiratory flow at $25 \%$ of $\mathrm{FVC}$ ), expressed as $\%$ of predicted.

${ }^{\mathrm{c}}$ Odds ratio (95\% confidence interval) adjusted for RSV etiology of early wheezing and current antiinflammatory asthma medication (during the preceding 12 months) 